\title{
Complementary expression of calcium binding proteins delineates the functional organization of the locomotor network
}

\author{
Eva M. Berg ${ }^{1} \cdot$ Maria Bertuzzi ${ }^{1} \cdot$ Konstantinos Ampatzis ${ }^{1}[$
}

Received: 6 October 2017 / Accepted: 30 January 2018 / Published online: 8 February 2018

(c) The Author(s) 2018. This article is an open access publication

\begin{abstract}
Neuronal networks in the spinal cord generate and execute all locomotor-related movements by transforming descending signals from supraspinal areas into appropriate rhythmic activity patterns. In these spinal networks, neurons that arise from the same progenitor domain share similar distribution patterns, neurotransmitter phenotypes, morphological and electrophysiological features. However, subgroups of them participate in different functionally distinct microcircuits to produce locomotion at different speeds and of different modalities. To better understand the nature of this network complexity, here we characterized the distribution of parvalbumin (PV), calbindin D-28 k (CB) and calretinin (CR) which are regulators of intracellular calcium levels and can serve as anatomical markers for morphologically and potential functionally distinct neuronal subpopulations. We observed wide expression of CBPs in the adult zebrafish, in several spinal and reticulospinal neuronal populations with a diverse neurotransmitter phenotype. We also found that several spinal motoneurons express CR and PV. However, only the motoneuron pools that are responsible for generation of fast locomotion were CR-positive. CR can thus be used as a marker for fast motoneurons and might potentially label the fast locomotor module. Moreover, CB was mainly observed in the neuronal progenitor cells that are distributed around the central canal. Thus, our results suggest that during development the spinal neurons utilize $\mathrm{CB}$ and as the neurons mature and establish a neurotransmitter phenotype they use CR or/and PV. The detailed characterization of CBPs expression, in the spinal cord and brainstem neurons, is a crucial step toward a better understanding of the development and functionality of neuronal locomotor networks.
\end{abstract}

Keywords Calbindin $\cdot$ Calretinin $\cdot$ Parvalbumin $\cdot$ Spinal cord $\cdot$ Zebrafish

$\begin{array}{ll}\text { Abbreviations } \\ \text { 5-HT } & \text { 5-hydroxytryptamine (serotonin) } \\ \text { CB } & \text { Calbindin D-28 k } \\ \text { CBPs } & \text { Calcium binding proteins } \\ \text { CC } & \text { Central canal } \\ \text { ChAT } & \text { Choline-acetyltransferase } \\ \text { CR } & \text { Calretinin } \\ \text { D } & \text { Dorsal } \\ \text { DON } & \text { Descending octaval nucleus } \\ \text { GABA } & \gamma \text {-Aminobutyric acid } \\ \text { Glut } & \text { Glutamate } \\ \text { IMRF } & \text { Intermediate reticular formation } \\ \text { IRF } & \text { Inferior reticular formation }\end{array}$

Eva M. Berg and Maria Bertuzzi contributed equally.

Konstantinos Ampatzis

Konstantinos.Ampatzis@ki.se

1 Department of Neuroscience, Karolinska Institutet, 17177 Stockholm, Sweden

$\begin{array}{ll}\text { MA } & \text { Mauthner cell axon } \\ \text { Mlf } & \text { Medial longitudinal fascicle } \\ \text { MN } & \text { Motoneuron } \\ \text { Nmlf } & \text { Nucleus of the medial longitudinal fascicle } \\ \text { P } & \text { Posterior } \\ \text { PV } & \text { Parvalbumin } \\ \text { RV } & \text { Rhombencephalic ventricle } \\ \text { SRF } & \text { Superior reticular formation } \\ \text { TeV } & \text { Tectal ventricle } \\ \text { V } & \text { Ventral } \\ \text { Va } & \text { Valvula cerebellum }\end{array}$

\section{Introduction}

A plethora of neuronal functions were attributed to calcium binding proteins (CBPs), including neuronal excitability, neurotransmitter release, and excitotoxicity (Baimbridge et al. 1992; Andressen et al. 1993; Schwaller et al. 2002). Calretinin (CR), calbindin D28-k (CB) and parvalbumin 
(PV) are three major EF-hand CBPs that play significant roles in the regulation of intracellular $\mathrm{Ca}^{2+}$ homeostasis by buffering and transporting $\mathrm{Ca}^{2+}$ (Blaustein 1988; Heizman and Braun 1992; Andressen et al. 1993; Chard et al. 1993; Berridge et al. 2000). Although the precise physiological function of PV, CB and CR is still not fully understood, each of them individually or in combinations has been demonstrated to be a valuable marker of separate neuron populations in the vertebrate central nervous system (Arai et al. 1991; Baimbridge et al. 1992; Resibois and Rogers 1992; Andressen et al. 1993; Kress et al. 2015) including the spinal cord (Fournet et al. 1986; Antal et al. 1990, 1991; Celio 1990; Ince et al. 1993; Ren et al. 1993; Megías et al. 2003; Anelli and Heckman 2005; Morona et al. 2006a, b). The presence of CBPs in different neuronal populations, such as cholinergic, GABAergic, glutamatergic and nitrinergic (Baimbridge et al. 1992), supports the notion that CBPs are not associated to any neurochemical specificity of neurons. However, in numerous studied areas within the nervous system, they are localized in nearly non-overlapping cell assemblies. This segregated distribution pattern allows the identification of subgroups within nuclei that represent discrete neuronal micro-circuits, which are not cyto-architecturally separated (Andressen et al. 1993), but may perform different functions.

In all vertebrates, locomotion relies on the activation of central pattern-generating networks located within the spinal cord (Grillner 2003, 2006; Goulding 2009; Kiehn 2006; Grillner and Jessell 2009). These defined spinal networks transform descending supraspinal signals to generate movements with diverse speeds and of different modalities (Grillner and Jessell 2009; Esposito et al. 2014; Kiehn 2016), and they are formed by a highly heterogeneous population of neurons. An important step towards understanding the principles that govern the organization and functionality of spinal locomotor circuits is to determine the identity of the different spinal neuron populations. Numerous types of neurons have been already described based on their developmental origin, and morphological and electrophysiological properties in the vertebrate spinal cord (Jankowska 1992; Jessell 2000; Briscoe and Ericson 2001; Lee and Pfaff 2001; Goulding et al. 2002; Sueiro et al. 2004; Grillner 2006; Kiehn 2006; Lewis 2006; Windhorst 2007; McCrea and Rybak 2008; Mahmood et al. 2009; Berkowitz et al. 2010; Bikoff et al. 2016) including zebrafish (Bernhardt et al. 1990; Hale et al. 2001; Drapeau et al. 2002; McLean and Fetcho 2004; Higashijima et al. 2004a, b, c; Kimura et al. 2008; Satou et al. 2009, 2012; Bradley et al. 2010; Ampatzis et al. 2013; Ferg et al. 2014; Menelaou et al. 2014; Böhm et al. 2016). The continuous adjustment of locomotor speed relies on the precise recruitment of distinct spinal interneurons and motoneurons. While neurons that belong to the same populations in zebrafish spinal cord, as they arise from the same progenitor pool, share similar morphological and electrophysiological properties and release the same neurotransmitter, they are functionally distinct, in terms of their recruitment plan (McLean et al. 2007; Gabriel et al. 2011; Ausborn et al. 2012; Ampatzis et al. 2013; Kishore et al. 2014; Menelaou et al. 2014; Björnfors and El Manira 2016). To this end, studies in adult zebrafish have shown that the generation of locomotion at different speeds relies on sequential activation of functionally distinct subpopulations (slow, intermediate and fast) of interneurons (Ausborn et al. 2012; Ampatzis et al. 2014; Björnfors and El Manira 2016) and motoneurons (Gabriel et al. 2011; Ampatzis et al. 2013). To understand further the nature of this functional complexity of spinal circuitry organization, we characterized the distribution pattern of CBPs, regulators of intracellular calcium that serve as valuable anatomical markers for morphologically and potential functionally distinct neuronal subpopulations. In the present work, we provide a detailed description of the distribution pattern of calretinin (CR), calbindin D28-k (CB) and parvalbumin (PV) containing neurons to determine the relationship between the type of calcium binding proteins present in adult zebrafish spinal cord and brain descending neurons and the accompanying function.

We first show that CR and PV containing neurons were co-distributed and occasionally co-localized in motoneurons and interneurons with a diverse neurotransmitter phenotype in the adult zebrafish spinal cord. In contrast, CB immunoreactivity was observed in neuronal progenitor cells that were distributed around the central canal. We then show that the calcium binding protein $\mathrm{CR}$ is highly expressed in fast and in few intermediate motoneurons but not in slow motoneurons. Our results suggest that during development the spinal cord neurons utilize $\mathrm{CB}$ as an intracellular buffer protein and as they mature and establish a neurotransmitter phenotype they use CR or/and PV. Moreover, our findings propose that motoneurons which are involved in fast modalities of locomotion, such as fast swimming and escape, require an additional regulator for their intracellular calcium, and therefore CR can be potentially used as an anatomical marker for the fast locomotor system. We believe that such comprehensive analysis is necessary and potentially highly valuable as a framework for ongoing and future studies in the spinal neuronal networks controlling generation of locomotion at different speeds and modalities.

\section{Materials and methods}

\section{Experimental animals}

All animals were raised and kept in the core facility at the Karolinska Institute according to established procedures. 
Adult zebrafish (Danio rerio; $n=190 ; 10-12$ weeks old; length, 16-19 mm; weight, 0.03-0.05 g) wild type (AB/ Tübingen) of either sex where used in this study.

\section{Motoneuron and descending neuron labeling}

Zebrafish $(n=48)$ of either sex were anesthetized in $0.03 \%$ tricaine methane sulfonate (MS-222, Sigma-Aldrich) and placed, lying lateral side up, onto a wet paper tissue inside a petri dish. Retrograde labeling of axial motoneurons was performed by dye injections of tetramethylrhodamine-dextran (3000 MW; ThermoFisher, D3307) into specific muscle fiber types (slow, intermediate or fast), which in the adult zebrafish are arranged in an anatomically segregated manner, as described before in detail (Ampatzis et al. 2013). In addition, retrograde labeling of all motoneurons was performed by applying similar procedures to spinal cord ventral roots. To label the neurons descending from the brain to the spinal cord, dye was injected into the spinal cord at approximately the level of the 8-10th vertebra. Afterwards, animals were kept for at least $24 \mathrm{~h}$ to allow for retrograde transport of the tracer.

\section{Immunohistochemistry}

All animals were deeply anesthetized with $0.1 \%$ MS-222. We then dissected the spinal cords and/or the brains and fixed them in $4 \%$ paraformaldehyde (PFA) in phosphate buffer saline (PBS) (0.01M; pH 7.4) at $4{ }^{\circ} \mathrm{C}$ for $2-14 \mathrm{~h}$. We performed immunolabeling in both whole mount spinal cords and in cryosections. For cryosections, the tissue was removed carefully and cryoprotected overnight in $30 \%$ (w/v) sucrose in PBS at $4{ }^{\circ} \mathrm{C}$, embedded in OCT Cryomount (Histolab), rapidly frozen in dry-ice-cooled isopentane (2-methylbutane; Sigma) at approximately $-35^{\circ} \mathrm{C}$, and stored at $-80{ }^{\circ} \mathrm{C}$ until use. Transverse coronal plane cryosections (thickness $25 \mu \mathrm{m}$ ) of the tissue were collected and processed for immunohistochemistry. In all cases, the tissue was washed three times for $5 \mathrm{~min}$ in PBS. Nonspecific protein binding sites were blocked with $4 \%$ normal donkey serum with $1 \%$ bovine serum albumin (BSA; Sigma) and $1 \%$ Triton X-100 (Sigma) in PBS for $30 \mathrm{~min}$ at room temperature (RT). Primary antibodies (Table 1) were diluted in $1 \%$ of blocking solution and applied for $24-90 \mathrm{~h}$ at $4{ }^{\circ} \mathrm{C}$. After thorough buffer rinses, the tissue was then incubated with the appropriate secondary antibodies (Table 1) diluted 1:500 in 1\% Triton X-100 (Sigma) in PBS overnight at $4{ }^{\circ} \mathrm{C}$. Finally, the tissue was thoroughly rinsed in PBS and cover-slipped with fluorescent hard medium (VectorLabs; H-1400).

The antibodies used in this study have been widely used in zebrafish before and have been described to reliably identify neurotransmitter phenotypes (anti-ChAT: Clemente et al. 2004; Mueller et al. 2004, 2006; Reimer et al. 2008; Moly et al. 2014; Ohnmacht et al. 2016; anti-GABA; Higashijima et al. 2004a; Montgomery et al. 2016; Djenoune et al. 2017; anti-Glycine; anti-Serotonin; Kuscha et al. 2012; McPherson et al. 2016). To further evaluate the antibody specificity, adjacent sections or additional whole mount spinal cords were used in the absence of the first or second antibody. In all cases, no residual immunolabeling was detected. Furthermore, to assess the specificity of antibodies against the selected neurotransmitters (GABA, glutamate, glycine and serotonin), we pre-incubated the neurotransmitter antibodies used in this study with their corresponding antigen for $1 \mathrm{~h}$ at RT (100-400 $\mu \mathrm{M})$ GABA (A2129, Sigma-Aldrich), glutamate (G3291, Sigma-Aldrich), glycine (G6761, Sigma-Aldrich), and serotonin (14927, Sigma-Aldrich) which eliminated any immunoreactivity. In addition, we performed similar experiments in transgenic zebrafish lines (Gad1b:GFP, Vglut2:GFP, Glyt2:GFP and Tph2:GFP), in which the majority of the respective neurons express green

Table 1 Antibodies used

\begin{tabular}{|c|c|c|c|c|}
\hline Antigen & Host & Source & Code & Dilution \\
\hline \multicolumn{5}{|l|}{ Primary } \\
\hline PV & Mouse & Swant & 235 & $1: 3000$ \\
\hline PV & Rabbit & Swant & PV27 & $1: 3000$ \\
\hline $\mathrm{CR}$ & Rabbit & Swant & CR7697 & $1: 500$ \\
\hline $\mathrm{CR}$ & Mouse & Swant & $6 \mathrm{~B} 3$ & $1: 1000$ \\
\hline CB D-28 k & Mouse & Swant & 300 & $1: 2000$ \\
\hline CB D-28 k & Rabbit & Millipore & AB 1778 & $1: 200$ \\
\hline ChAT & Goat & Chemicon & AB144P & $1: 150$ \\
\hline Islet 1 & Mouse & DSHB & $40.2 \mathrm{D} 6$ & $1: 100$ \\
\hline GABA & Rabbit & Sigma & A2052 & $1: 2000$ \\
\hline Glycine & Rat & $\begin{array}{l}\text { ImmunoSolu- } \\
\text { tion }\end{array}$ & IG1002 & $1: 1000$ \\
\hline Glutamate & Rabbit & Sigma & G6642 & $1: 4000$ \\
\hline Serotonin & Rabbit & Sigma & S5545 & $1: 4000$ \\
\hline Sox-2 & Goat & R\&D Systems & AF2018 & $1: 500$ \\
\hline $\begin{array}{l}\text { Elav3 + } 4 \\
(\mathrm{HuC} / \mathrm{D})\end{array}$ & Rabbit & GeneTex & GTX128365 & $1: 500$ \\
\hline \multicolumn{5}{|l|}{ Secondary } \\
\hline Goat IgG-568 & Donkey & ThermoFisher & A-11057 & $1: 500$ \\
\hline $\begin{array}{l}\text { Mouse IgG- } \\
647\end{array}$ & Donkey & ThermoFisher & A-31571 & $1: 500$ \\
\hline $\begin{array}{l}\text { Mouse IgG- } \\
568\end{array}$ & Goat & ThermoFisher & A-11004 & $1: 500$ \\
\hline $\begin{array}{l}\text { Mouse IgG- } \\
488\end{array}$ & Donkey & ThermoFisher & A-21202 & $1: 500$ \\
\hline Rat IgG-550 & Donkey & ThermoFisher & SA5-10027 & $1: 500$ \\
\hline $\begin{array}{l}\text { Rabbit IgG- } \\
488\end{array}$ & Donkey & ThermoFisher & A-21206 & $1: 500$ \\
\hline $\begin{array}{l}\text { Rabbit IgG- } \\
568\end{array}$ & Donkey & ThermoFisher & A-10042 & $1: 500$ \\
\hline
\end{tabular}

$C B$ calbindin D-28 k, $C R$ calretinin, $P V$ parvalbumin, $C h A T$ cholineacetyltransferase, $G A B A \gamma$-Aminobutyric acid 
fluorescent protein (GFP). In all cases, most of the GFP ${ }^{+}$ neurons were also immunolabeled with antibodies (data not shown) suggesting the specificity of our immunodetection.

\section{Analysis}

Imaging was carried out in a laser scanning confocal microscope (LSM 510 Meta, Zeiss). Cell counting was performed in segment 15 of the adult zebrafish spinal cord (in whole mount preparations), or in non-overlapping fields of spinal cord sections, between 14 and 16 spinal cord segments. The relative position of the somata of neurons within the spinal cord was calculated in whole mount preparations, using the lateral, dorsal, and ventral edges of the spinal cord as well as the central canal as landmarks. The relative position was calculated using ImageJ. Examination of the descending neurons was performed from a series of coronal brain sections, throughout the brain. Cells of each analyzed brain area were counted in a section that sampled the area well. The nomenclature used for the brain areas of descending neurons was based on the topological zebrafish brain atlas (Wullimann et al. 1996). All figures and graphs were prepared with Adobe Photoshop and Adobe Illustrator (Adobe Systems Inc., San Jose, CA, USA). Digital modifications of the images (changes in brightness and contrast) were minimal to not affect the biological information. All images from double-labeling immunofluoresence experiments were post hoc converted to magenta-green to make this work more accessible to red-green color-blind readers.

\section{Statistics}

The significance of differences between the means in experimental animal groups for the detection of CBPs was analyzed using One-way ANOVA followed by post hoc Tukey, using Prism (GraphPad Software Inc.). Differences were considered to be significant if $p<0.05$. Data presented here are given as mean \pm SEM.

\section{Results}

\section{Distribution pattern of calcium binding proteins in the adult zebrafish spinal cord}

To determine the expression pattern of the three major CBPs (CR, CB and PV), we analyzed their immunoreactivity in the whole hemisegment that corresponds to segment 15 of the adult zebrafish spinal cord. The detailed distribution analysis revealed that $\mathrm{CR}^{+}$and $\mathrm{PV}^{+}$neurons are co-distributed throughout the motor column, from the most ventrolateral to middle part (Fig. 1a, c, d, f). In addition to the neuronal somata staining observed, profuse fiber labeling was also present in the neuropil (Fig. 1a, c) where the spinal motoneuron and interneuron dendrites are extending. Immunoreactivity for both $\mathrm{CR}$ and $\mathrm{PV}$ was observed in various body sized neurons $\left(\mathrm{CR}^{+}: 61.57 \pm 4.85 \mu \mathrm{m}^{2}\right.$, $n=3$ zebrafish; $\mathrm{PV}^{+}: 72.87 \pm 5.68 \mu \mathrm{m}^{2}, n=3$ zebrafish; Fig. 1h,i). Analysis of the complete number of $\mathrm{CB}^{+}$neurons in zebrafish spinal cord hemisegment revealed a neuronal population significantly larger $(136.2 \pm 3.19$ neurons/ hemisegment, $n=7$ zebrafish, Fig. $1 \mathrm{~g}$ ) than that observed for $\mathrm{CR}$ and $\mathrm{PV}\left(\mathrm{CR}^{+}: 56.57 \pm 2.94\right.$ neurons/hemisegment, $n=6$ zebrafish; $\mathrm{PV}^{+}: 43.5 \pm 0.99$ neurons/hemisegment, $n=6$ zebrafish, Fig. $1 \mathrm{~g}$ ). Numerous small sized $\mathrm{CB}^{+}$neurons $\left(22.51 \pm 0.39 \mu \mathrm{m}^{2}, n=3\right.$ zebrafish, Fig. 1i) were primarily present in the middle part of the spinal cord, in close apposition to the central canal. Dorsal spinal regions practically lacked the selected $\mathrm{CBP}^{+}$cells. Overall, these observations were extremely consistent from animal to animal.

The wide co-distribution of $\mathrm{CR}^{+}$and $\mathrm{PV}^{+}$neurons in the same area of the adult zebrafish spinal cord and their expression in almost similar sized neurons (Figs. 1i, 2a) strongly suggested the possibility of co-localization of both CBPs in the same population of neurons. Thus, to test and estimate the proportion of co-localization of the different CBPs in neurons, double-labeling experiments were performed. There was no co-expression of $\mathrm{CB}$ with either of the other calcium buffering proteins (CR or PV, $n=6$ zebrafish, Fig. $2 \mathrm{a}-\mathrm{c}$ ). In contrast, the majority of $\mathrm{PV}^{+}$neurons were found to express also $\mathrm{CR}\left(\mathrm{CR}^{+} \mathrm{PV}^{+}\right.$: $51 \%, n=8$ zebrafish, Fig. 2 d, e). In addition, a population of $\mathrm{CR}^{+} \mathrm{PV}^{-}$neurons $(41 \%)$ and a small population of $\mathrm{CR}^{-} \mathrm{PV}^{+}$neurons (8\%) were also detected (Fig. 2e). Overall, these data clearly show distinct cytoarchitectural distribution patterns of $\mathrm{CR}^{+}, \mathrm{CB}^{+}$and $\mathrm{PV}^{+}$neurons in adult zebrafish spinal cord.

\section{Calcium binding proteins are localized in distinct neurochemical populations}

Neuronal control of movements is organized by a heterogeneous population of spinal neurons (interneurons and motoneurons) characterized by specific neurotransmitter phenotypes (Grillner 2003; Kiehn 2006; Goulding 2009). To explore the relationship between CBP expression and neurotransmitter typology of different spinal neuronal populations, we sought to establish a detailed map of CR, $\mathrm{CB}$ or PV immunoreactivity in GABAergic, glycinergic, glutamatergic, cholinergic and serotonergic neurons in the adult zebrafish spinal cord. 

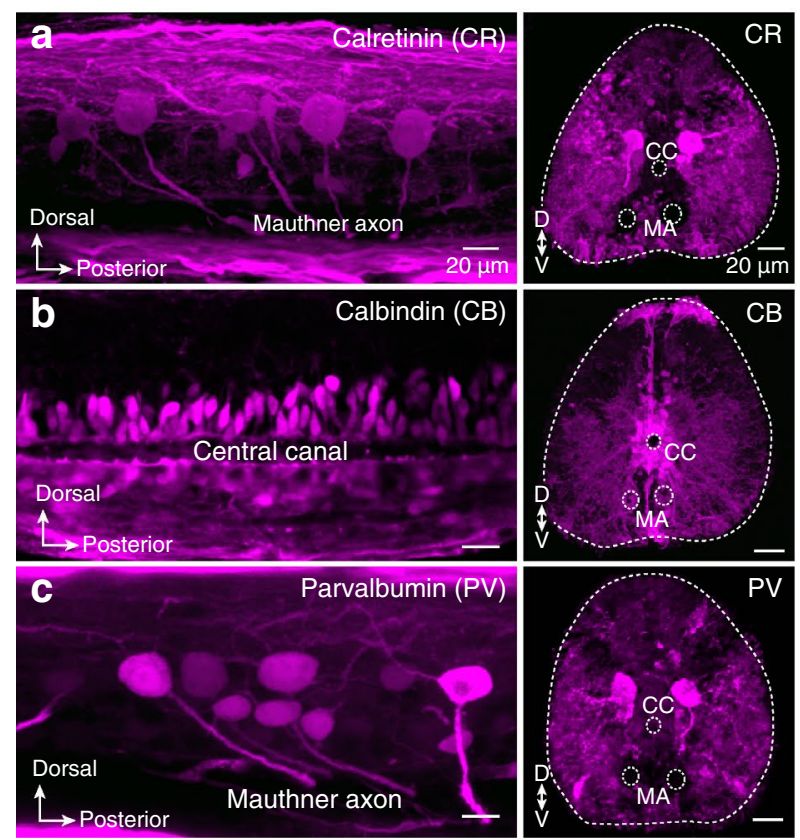

Fig. 1 Overview of calretinin (CR), calbindin (CB) and parvalbumin (PV) expression in the adult zebrafish spinal cord. a-c Expression of CBPs in whole mount and transverse sections of the adult zebrafish spinal cord (segment 15). d-f Representative setting positions of the CR, CB and PV positive neurons in spinal hemisegments $15 . \mathrm{g}$ Number of $\mathrm{CR}, \mathrm{CB}$ and $\mathrm{PV}$ positive neurons per adult zebrafish spi-

In the vertebrate nervous system, the presence of calcium binding proteins is often associated with specific neurotransmitter phenotypes (Katsumaru et al. 1988; Celio 1990; Andressen et al. 1993). However, the reason why some cell types express $\mathrm{CR}, \mathrm{CB}$, or PV and correlate to neurons with a specific neurotransmitter phenotype is not clear yet. Double immunofluorescence experiments revealed that fractions of CR containing neurons were GABAergic $(26.27 \pm 2.36 \%$, $n=6$ zebrafish), glycinergic $(20.54 \pm 2.75 \%, n=4$ zebrafish), glutamatergic $(50.51 \pm 2.47 \%, n=7$ zebrafish), cholinergic $(42.04 \pm 1.32 \%, n=5$ zebrafish) and serotonergic $(5.44 \pm 0.45 \%, n=6$ zebrafish) (Fig. 3a, d). None of the $\mathrm{PV}^{+}$neurons were found to be GABAergic $(n=5$ zebrafish) or serotonergic ( $n=5$ zebrafish). However, similar to CR immunoreactivity, $7.52 \pm 0.59 \%$ ( $n=5$ zebrafish), $5.48 \pm 0.58 \%$ ( $n=8$ zebrafish $)$ and $45.51 \pm 2.45 \%(n=6$ zebrafish) of $\mathrm{PV}^{+}$neurons were glycinergic, glutamatergic and cholinergic neurons, respectively (Fig. 3c, f). Despite the high degree of co-distribution between $\mathrm{CB}^{+}$and $\mathrm{GABA}^{+}$ neurons, no double-labeled cells were observed in the middle part of the spinal cord close to central canal (Fig. 3b, e). In addition, none of the $\mathrm{CB}^{+}$neurons were found to express glutamate ( $n=6$ zebrafish) or ChAT ( $n=4$ zebrafish), and only few $\mathrm{CB}^{+}$Glycine $^{+}(2.85 \pm 0.29 \%, n=5$ zebrafish $)$ and $\mathrm{CB}^{+}$Serotonin ${ }^{+}(0.49 \pm 0.15 \%, n=7$ zebrafish $)$ neurons were observed (Fig. 3b, e). Collectively, these data reveal that
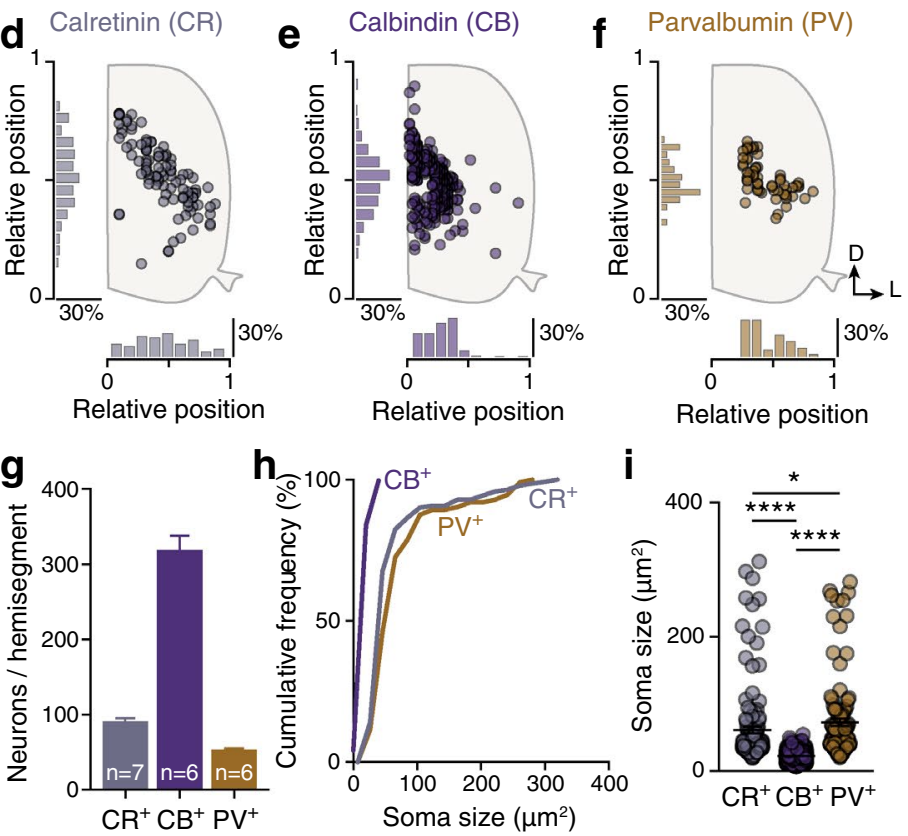

nal hemisegment. h, i Cumulative frequency (h) and average of soma sizes for $\mathrm{CR}, \mathrm{CB}$ and $\mathrm{PV}$ positive neurons. The soma size between $\mathrm{CR}, \mathrm{CB}$ and PV containing neurons is different (one-way ANOVA: $\left.F_{(2,645)}=110, p<0.0001\right)$. Data are presented as mean \pm SEM; asterisks indicate statistical significance. $* p<0.05$; $* * * * p<0.0001$

$\mathrm{CR}^{+}$and $\mathrm{PV}^{+}$neurons localized in a phenotypically heterogeneous population of inhibitory and excitatory interneurons and in motoneurons within the adult zebrafish spinal cord. Moreover, CB immunoreactivity was not specifically related to any particular major neurotransmitter phenotype neuronal population.

\section{Calretinin classifies the fast motoneuron module}

Numerous CR and PV containing neurons had a cholinergic neurochemical phenotype (Fig. 3a, c, d, f), which labels the motoneurons and the cholinergic interneurons in the adult zebrafish spinal cord. To test whether either of these CBPs co-localized with motoneurons, retrograde tracer was injected into ventral roots to label the motoneurons. Indeed, several motoneurons expressed CR $(53.25 \pm 2.74 \%$, $n=5$ zebrafish, Fig. $4 \mathrm{a}, \mathrm{b}$ ) and the vast majority of labeled motoneurons was found to express PV $(80.14 \pm 3.16 \%, n=5$ zebrafish, Fig. 4a, b).

To further determine the expression pattern of CR and $\mathrm{PV}$ in functionally different motoneuron pools (slow, intermediate, fast), retrograde tracer was injected into the respective different muscle fiber types by taking advantage of the accessible neuromuscular configuration of the adult zebrafish (Ampatzis et al. 2013). Overall, 90.32\% (28 out of 31 neurons), $89.65 \%$ (26 out of 29 neurons), $82.85 \%$ 

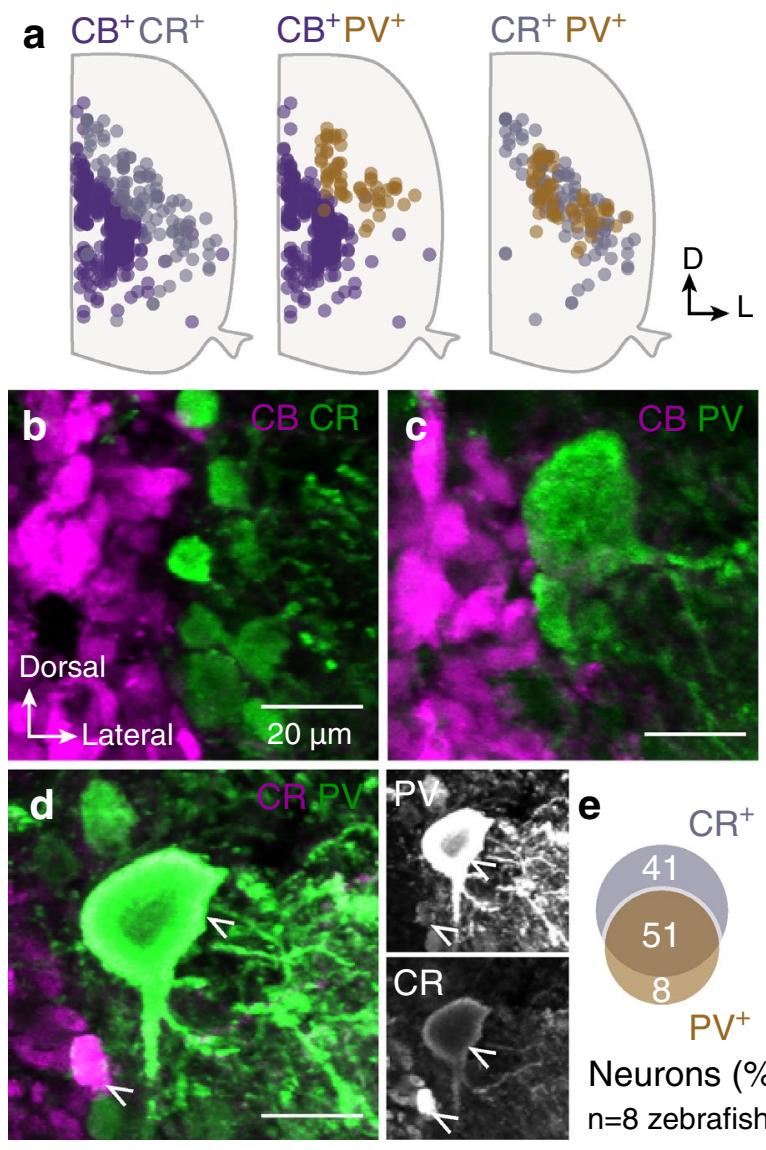

Neurons (\%) $\mathrm{n}=8$ zebrafish

Fig. 2 Co-distribution and co-localization of the CBPs positive neurons. a Superimposed positions of the $\mathrm{CR}, \mathrm{CB}$ and $\mathrm{PV}$ positive neurons in the spinal cord. b-d Double immunofluorescent images between the three studied CBPs (CR, CB and PV). Many double expressing neurons observed only between $\mathrm{CR}$ and $\mathrm{PV}$ (51\%; arrowheads in d). e Percentage of co-expression of CR, CB or PV in neurons. Only a small population of $\mathrm{PV}^{+}$neurons does not express $\mathrm{CR}$ (8\%; e). Single channel views of the respective framed box

(29 out of 35 neurons) and 100\% (15 out of 15 neurons) of slow, intermediate, fast and primary motoneurons, respectively, were immunoreactive for PV (Fig. 4c, d). In contrast, CR immunoreactivity was more confined to motoneurons responsible for the contraction of fast muscles. All primary motoneurons were $\mathrm{CR}^{+}(100 \% ; 14$ out of 14 neurons) as well as the vast majority of fast motoneurons (84.37\%; 4 out of 23 neurons) (Fig. 4c, d). In contrast, a small fraction of intermediate motoneurons was found to express CR (17.39\%; 27 out of 32 neurons) and none of the slow motoneurons contained CR $(0 \%$; 0 out of 27 neurons) (Fig. 4c, d). Our results thus suggest that $\mathrm{CR}^{+}$expression can be a potential marker of the fast module of the locomotor network (Ampatzis et al. 2014).

\section{Calcium binding protein expression in brain neurons that descend to the spinal cord and initiate locomotion}

Previous studies showed that the spinal locomotor circuitry of adult zebrafish is organized in three separate microcircuit modules named the slow, the intermediate and the fast (Ampatzis et al. 2014). Although spinal networks are capable and sufficient to produce all locomotion related movements (Grillner 2003, 2006; Grillner and Jessell 2009), the initiation of any motor event arises from descending signals from supraspinal areas (Grillner and Jessell 2009; Esposito et al. 2014; Kiehn 2016). To evaluate the distribution of CBPs in supraspinal neurons that innervate the spinal cord, and their potential to reveal and discriminate the possible existence of functionally segregated descending populations, a series of experiments combining tracing techniques and immunohistochemistry were conducted (Fig. 5a). The double-labeling experiments showed a wide distribution of $\mathrm{CR}^{+}$or $\mathrm{PV}^{+}$brain descending neurons in several brain areas (Fig. 5b, c). Retrogradely labeled brain neurons that showed CR and PV expression were observed in the nucleus of the medial longitudinal fascicle (Nmlf; PV: $87.35 \pm 7.68 \%, \quad C R: 60.19 \pm 5.3 \%$, Fig. 5f), superior reticular formation (SRF; PV: $88.51 \pm 4.76 \%$, CR: $77.92 \pm 6.46$, Fig. 5f), intermediate reticular formation (IMRF; PV: $90.94 \pm 4.6 \%$, CR: $74.31 \pm 3.29 \%$, Fig. 5f), inferior reticular formation (IRF; PV: $91.79 \pm 4 \%$, CR: $59.26 \pm 3.15 \%$, Fig. 5f), and in the descending octaval nucleus (DON; PV: $92.14 \pm 2.29 \%$, CR: $53.06 \pm 2.67 \%$, Fig. $5 f$ ). Our analysis showed that the vast majority of descending supraspinal neurons contained PV $(92.08 \pm 2.85 \%$, $n=6$ zebrafish), however, no more than $64.89 \pm 0.79 \%$ ( $n=7$ zebrafish) of these neurons were found to contain CR (Fig. 5e). Additionally, our analysis showed that none of the retrogradely labeled brain neurons expressed CB (Fig. 5d). Collectively, our data suggest that CR can be a valuable marker to define potentially functionally distinct subpopulations of brain to spinal cord descending neurons.

\section{Calbindin defines the spinal neuronal progenitors}

CB immunoreactivity was not specifically related with any particular major neurochemical phenotype (Fig. 3e). In addition, $\mathrm{CB}^{+}$cells were detected mainly around the central canal (Fig. 6a), the proliferation niche of the spinal cord (Grandel et al. 2006; Kaslin et al. 2008; Hui et al. 2015). This raises the possibility that $\mathrm{CB}$ might label undifferentiated new born cells. To test this hypothesis, we performed a series of experiments to identify the nature of the $\mathrm{CB}^{+}$ cells. We observed that none of the newly differentiated and migrated neurons (marked with mef-2 ${ }^{+}$) were $\mathrm{CB}^{+}$(Fig. 6b). 


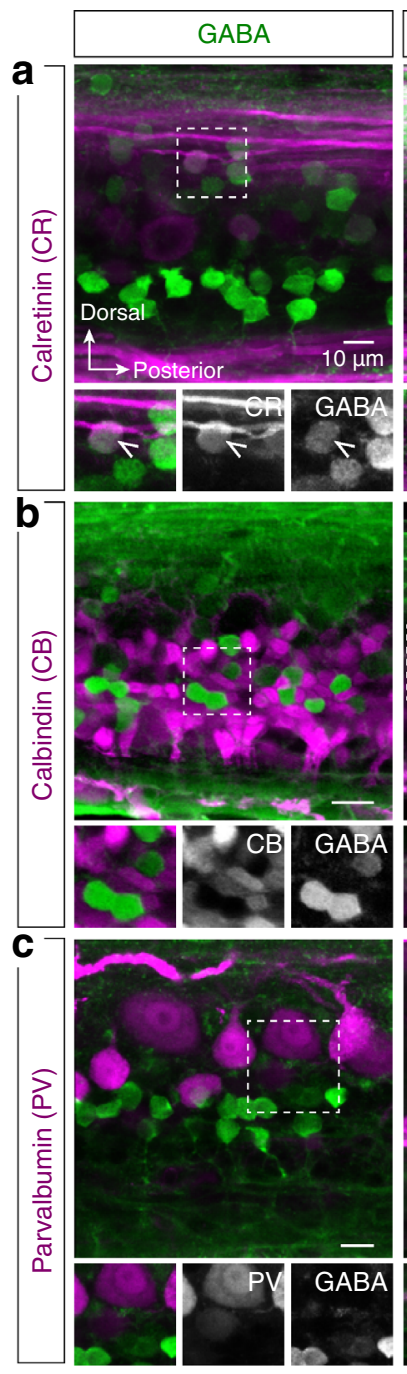

d

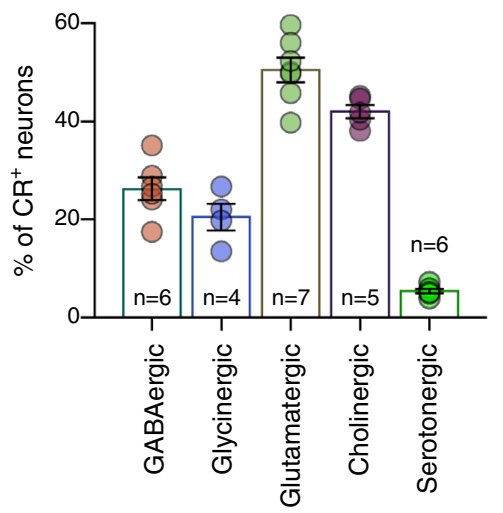

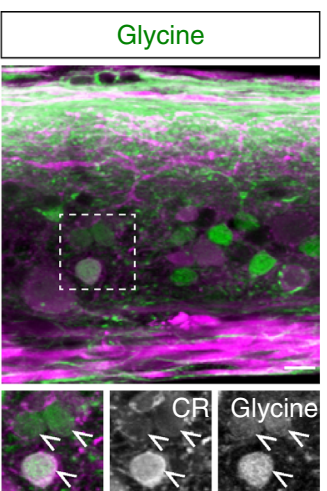
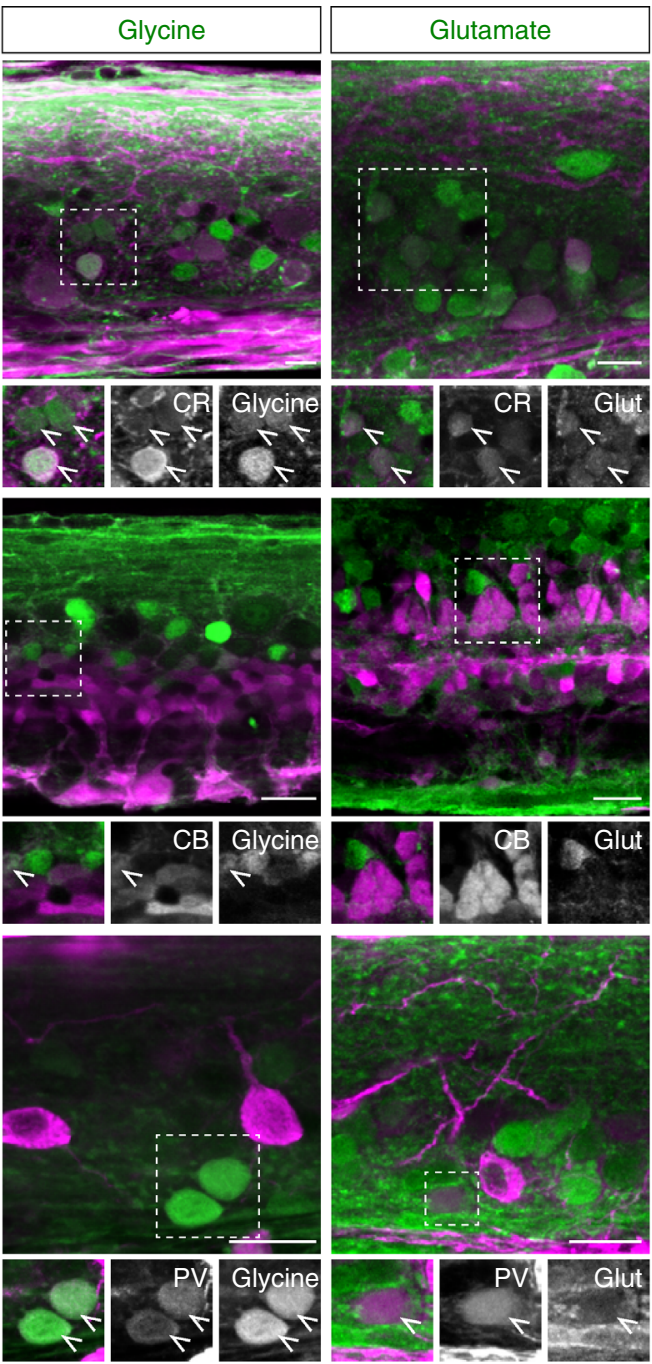

e
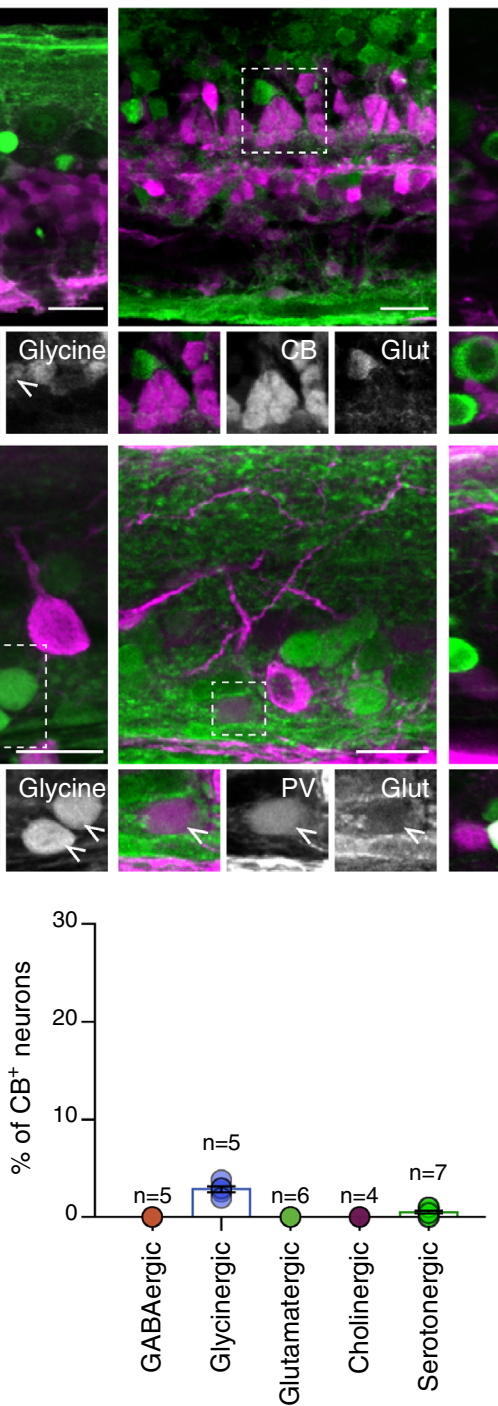
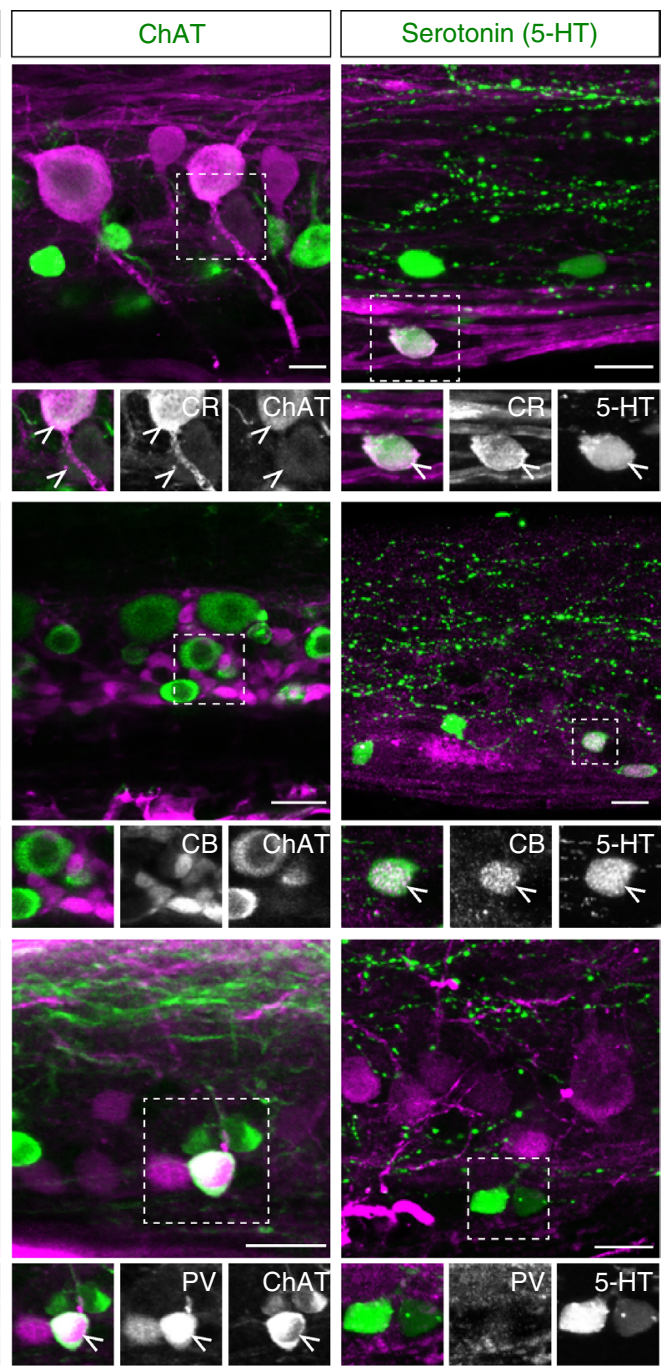

$\mathbf{f}$

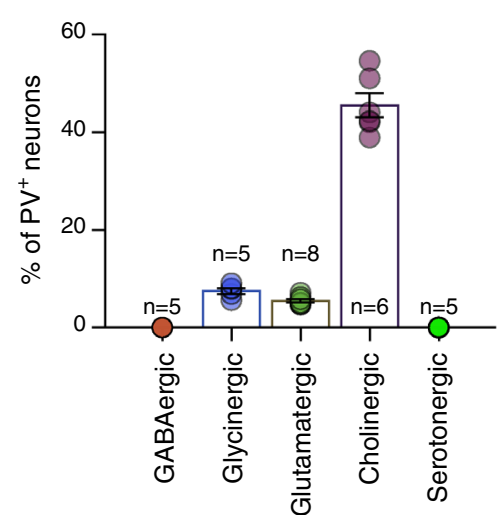

Fig. $3 \mathrm{CR}, \mathrm{CB}$ and PV expression in neurons with identified neurotransmitter type. a-c Double immunostaining experiments for $\mathrm{CR}$, $\mathrm{CB}$ and PV (magenta) with markers that label the GABAergic, glycinergic, glutamatergic, cholinergic and serotonergic spinal neurons (green) in whole mount adult zebrafish spinal preparations. Enlarged and single channel views are given for areas indicated by framed boxes. Arrowheads indicate double-labeled cells. d-f Quantification of the percentage of $\mathrm{CR}, \mathrm{CB}$ and $\mathrm{PV}$ positive neurons that localized in neurons with a specific neurotransmitter phenotype 


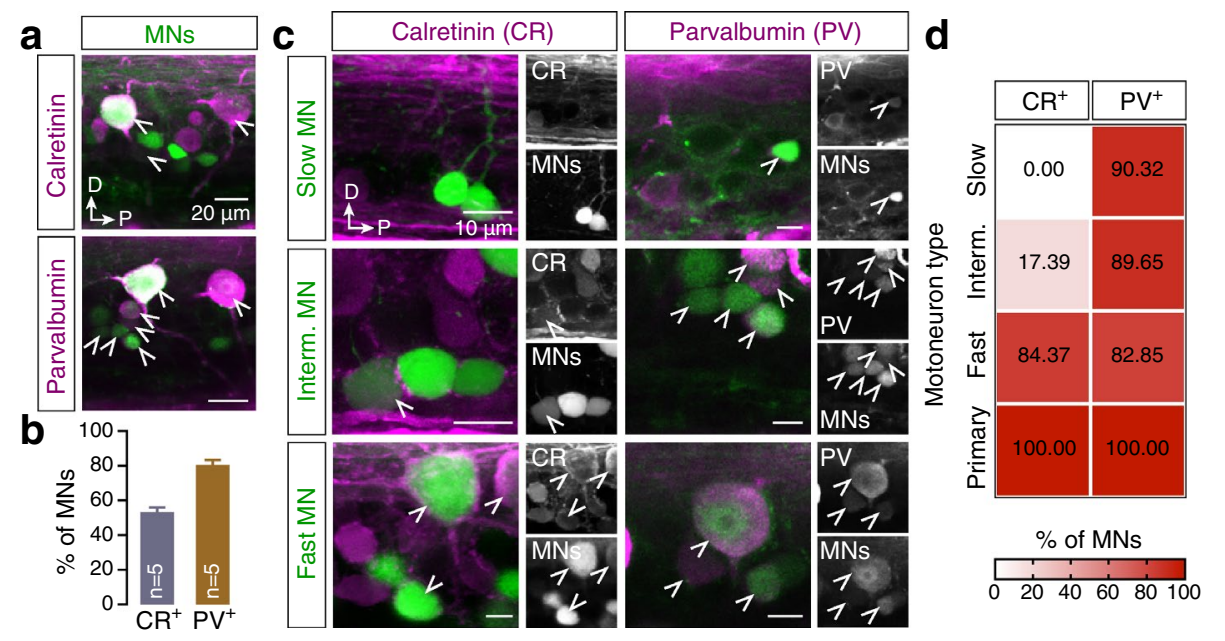

Fig. 4 Zebrafish axial motoneurons are immunoreactive to $\mathrm{CR}$ and $\mathrm{PV}$. a Representative images of the double-labeled motoneurons with $\mathrm{CR}$ and PV. b Quantification of the percentage of the motoneurons that express both CR and PV. c Whole mount images showing the expression of $\mathrm{CR}$ and $\mathrm{PV}$ in distinct motoneuron pools (slow, intermediate and fast). Single channel views of the respective images

Moreover, only a small fraction of $\mathrm{CB}^{+}$cells were found to express HuC/D $(2.32 \pm 0.561 \%, n=5$; Fig. $6 \mathrm{c}, \mathrm{e}, \mathrm{f})$ a marker for postmitotic neurons. Finally, we observed that the vast majority $\left(78.13 \pm 1.541 \%, n=35\right.$; Fig. $6 \mathrm{~d}$, e, f) of $\mathrm{CB}^{+}$cells co-expressed Sox-2, a marker for neuronal progenitor cells and stem cells (Ferri et al. 2004; Episkopou 2005; Wegner and Stolt 2005; Takahashi and Yamanaka 2006). Taken together, these findings demonstrate that $\mathrm{CB}$ can serve as a valuable anatomical marker to identify the mitotically active cells that are able to generate neurons in the spinal cord.

\section{Discussion}

The initiation and generation of locomotion depend on dedicated neurons located in the spinal cord and supraspinal areas (Grillner 2003, 2006; Grillner and Jessell 2009; Esposito et al. 2014; Kiehn 2016; Goulding 2009). However, the identity of the neurons that form the locomotor networks that are sufficient to initiate and generate any locomotor activity, at different speeds and modalities, still remains unclear. Here, we utilize CBP expression in spinal and in supraspinal areas as a potential tool to characterize the locomotor network neuronal infrastructure. The present study is the first to directly classify the spinal cord neurons' and the brain descending neurons' diversity, distribution and morphology with respect to the calcium binding proteins $\mathrm{CR}, \mathrm{CB}$ and $\mathrm{PV}$ in adult zebrafish. We show here that CBPs mark a highly heterogeneous population of neurons in the adult zebrafish spinal cord and in the reticulospinal areas. We also demonstrate that while most zebrafish axial motoneurons were shown for better visualization of CR or PV positive cells. Arrowheads indicate the double-labeled cells. $\mathbf{d}$ Color coded quantification of the CR and PV expression in distinct populations of neurons. The vast majority of motoneurons contain PV. CR expression is localized mainly in the motoneurons of the fast module

labeled with PV, only motoneurons that generate the high speeds of swimming or participate in the escape response were in addition CR immunoreactive (Fig. 7a). In extrapolation, our data suggest that $\mathrm{CR}$ can be a potential valuable marker for the fast locomotor microcircuit module, possibly marking also the interneuron population which is part of this module. Finally, we show that CB immunoreactivity was mainly confined to a large population of cells surrounding the central canal, and we revealed that the vast majority of these cells were progenitor cells/stem cells (Fig. 7b). Hence, we suggest that new born neurons utilize $\mathrm{CB}$ as a regulator of their intracellular calcium and when they mature and start expressing a neurotransmitter phenotype the vast majority uses other calcium regulator proteins such as $\mathrm{CR}$ and $\mathrm{PV}$ (Fig. 7b).

In the vertebrate nervous system, the presence of calcium binding proteins is often associated with specific neurotransmitter phenotypes (Katsumaru et al. 1988; Celio 1990; Andressen et al. 1993). For instance, PV has been usually observed in GABAergic neurons located in the hippocampus, cerebellum and cortex (Katsumaru et al. 1988; Celio 1990; Andressen et al. 1993), whereas CR and CB can be associated with both excitatory and inhibitory neurons (Celio 1986; Aoki et al. 1990; Reynolds and Beasley 2001). Our analysis clearly indicates that there is no obvious correlation between the CBPs studied here and a given neurotransmitter in the adult zebrafish spinal cord.

Currently in the spinal cord the only cell type that has been strongly associated with different CBPs are Renshaw cells (Arvidsson et al. 1992; Carr et al. 1998; Sapir et al. 2004; Alvarez et al. 2005). Renshaw cells are inhibitory 

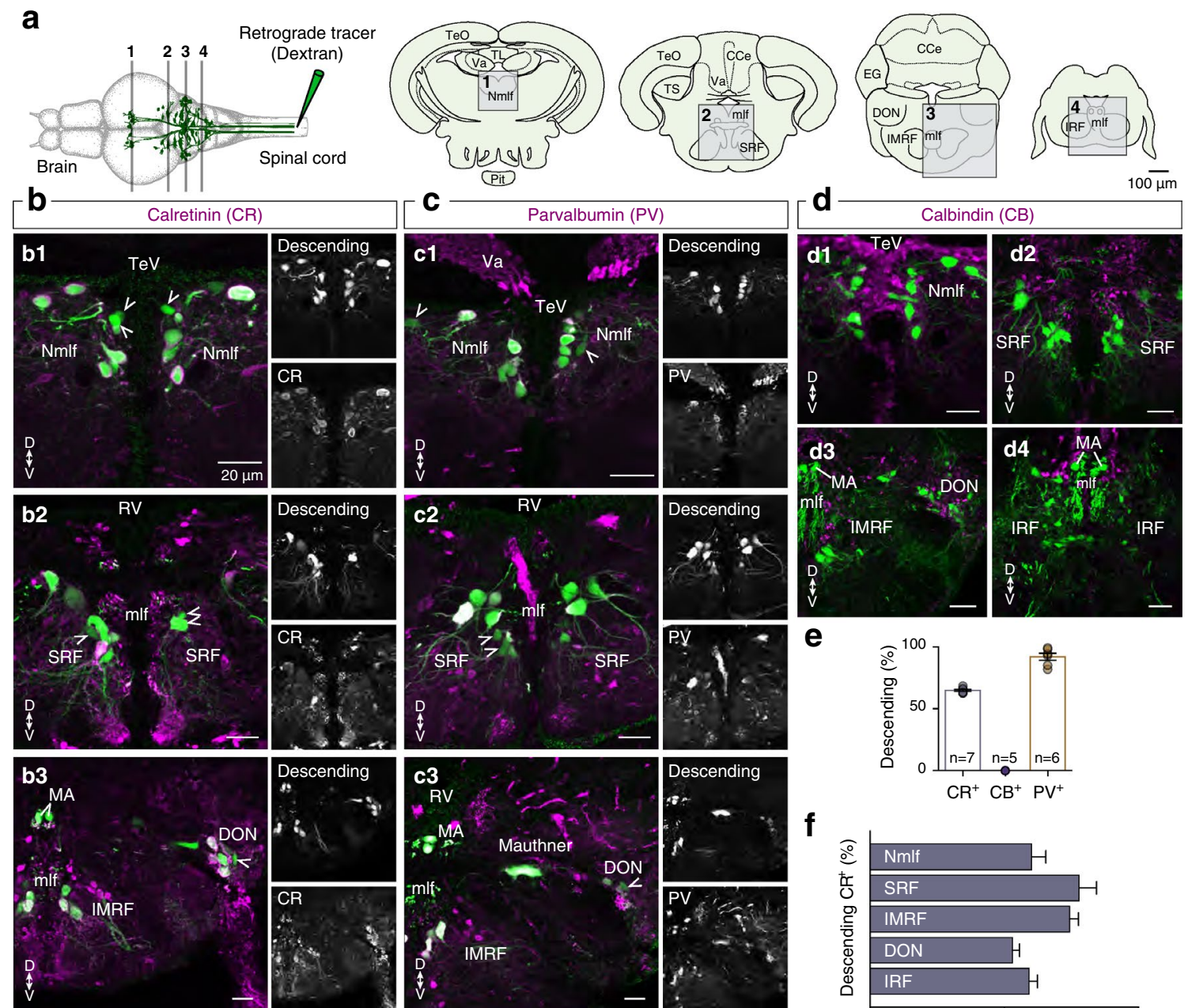

e
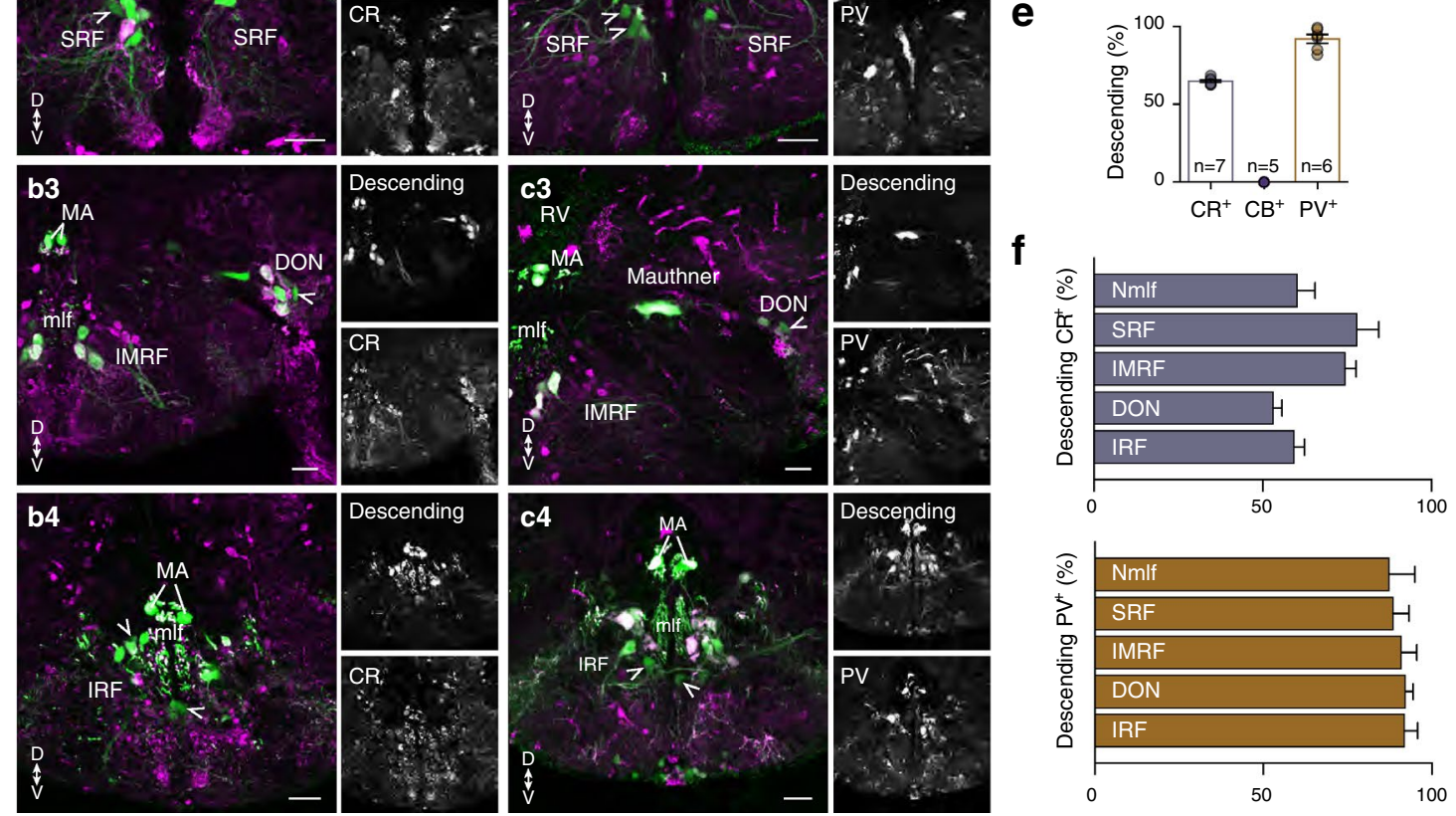

Fig. 5 Distribution pattern of $\mathrm{CR}, \mathrm{CB}$ and $\mathrm{PV}$ expression in reticulospinal neurons. a Schematic representation of the methodology used to reveal the brain neurons projecting to the spinal cord. The analyzed brain areas are indicated by boxes in coronal sections 1-4. b-d Microphotographs from coronal brain sections, showing the distribution of the brain neurons that project to the spinal cord (green) and the CR, CB and PV expression (magenta). Single channel views of the respective images shown for better visualization of the doublelabeled neurons. Arrowheads indicate the double-labeled cells. e Percentage of the reticulospinal neurons that express CR, CB or PV, respectively. $f$ Bar graph showing the percentage of brain to spinal cord projecting neurons in several brain areas that express CR or PV neurons deriving from the V1 population (Sapir et al. 2004; Alvarez et al. 2005) that release GABA or glycine to mediate recurrent inhibition to motoneurons (Cullheim and Kellerth 1981; Schneider and Fyffe 1992) and is well documented to contain CB and in a smaller degree also PV and CR (Sapir et al. 2004). Our findings demonstrate that a small population of neurons co-expresses CB and glycine in the adult zebrafish spinal cord. Although Renshaw cells have not been reported in the zebrafish spinal circuits, a previous study revealed that Engrailed-1 (a marker for V1 interneurons) is expressed in a small population of inhibitory glycinergic interneurons that possibly act in an analogous way to Renshaw cells in the mammalian spinal cord (Higashijima et al. 2004c). It is thus possible that these previously described 

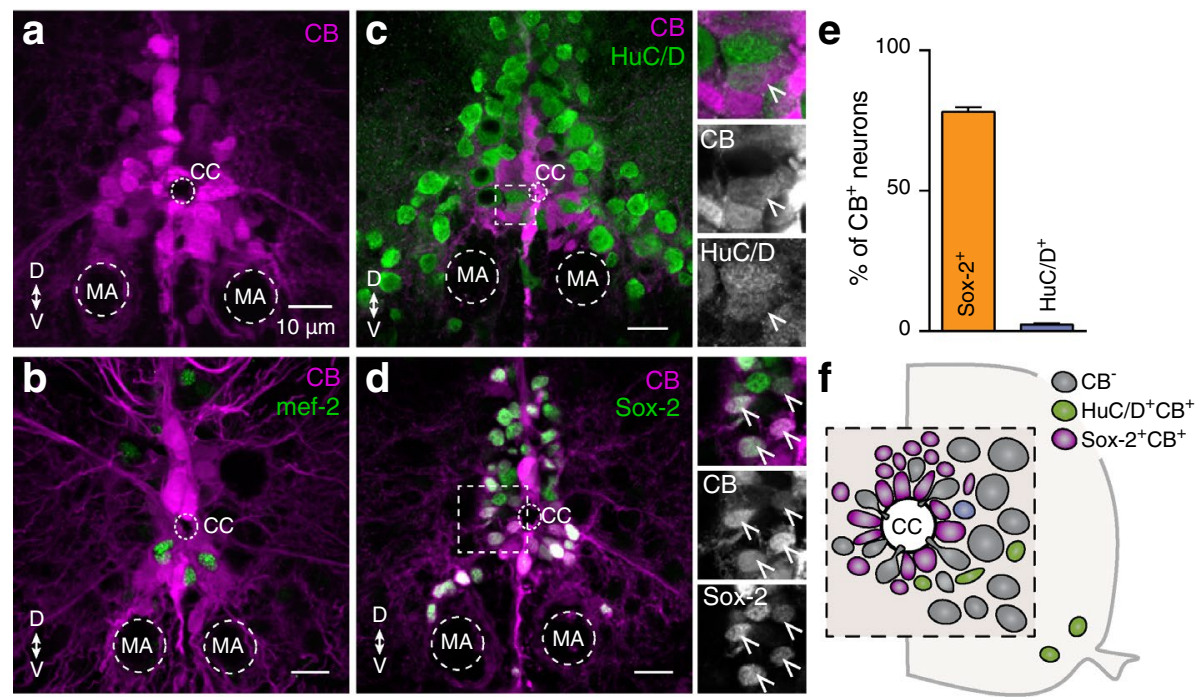

Fig. 6 Identity of the CB positive neurons. a Distribution pattern of $\mathrm{CB}^{+}$expression around the central canal in the adult zebrafish spinal cord. b None of the CB expressing cells (magenta) co-localized with the early neuronal differentiated marker mef-2 (green). c-d A small number $(2.32 \%)$ of the differentiated and mature neurons ( $\mathrm{HuC} /$ $\mathrm{D}^{+}$, green) contain also $\mathrm{CB}$ (magenta). In addition, the vast majority (78.13\%) of CB containing cells (magenta) is progenitor cells / stem

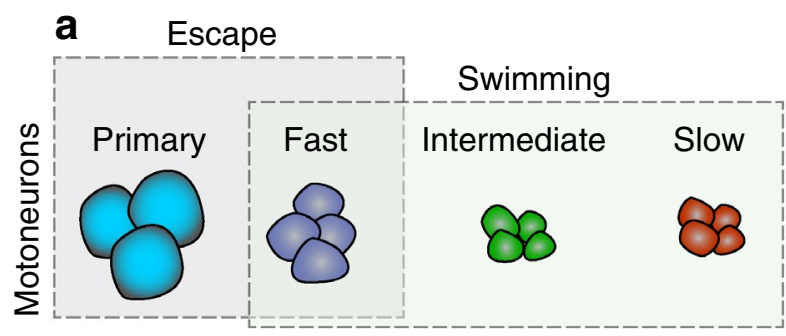

$$
\text { Parvalbumin }
$$

$$
\text { Calretinin }
$$

\section{b}

\section{Neuronal progenitors /} stem cells

Calbindin $\quad \begin{gathered}\text { Calretinin } \\ \text { Calbindin } \\ \text { Parvalbumin }\end{gathered}$

Fig. 7 Schematic of the differential expression of the CBPs in the adult zebrafish spinal cord. a Motoneuron pools that contribute to the generation of fast movements (fast swimming and escape) utilize both $\mathrm{CR}$ and $\mathrm{PV}$ as calcium buffer proteins. b The progenitor cells/stem cells utilize $\mathrm{CB}$ to buffer their intracellular calcium. The mature neurons mainly use $\mathrm{CR}$ and $\mathrm{PV}$ as a calcium binding proteins. This suggests that $\mathrm{CB}$ can serve as anatomical marker to identify the developmental events that generate neurons in the adult zebrafish spinal cord cells (Sox-2 $2^{+}$, green). Single channel views shown for areas are indicated by framed rectangles. Arrowheads indicate double labeled cells. e Quantification of CB positive cells that co-express Sox- $2^{+}$or $\mathrm{HuC} /$ $\mathrm{D}^{+}$. f Schematic representation of the central canal area in the adult zebrafish spinal cord showing that most of the $\mathrm{CB}^{+}$cells are progenitors / stem cells

Renshaw-like neurons in zebrafish contain also CB and constitute an evolutionary conserved population of neurons that later in the mammalian spinal cord forms the Renshaw cells, a question that should be addressed in further studies.

Several previous studies analyzed CBP expression in the vertebrate spinal cord (Fournet et al. 1986; Antal et al. 1990; Celio 1990; Ince et al. 1993; Ren et al. 1993; Sapir et al. 2004; Alvarez et al. 2005; Anelli and Heckman 2005; Morona et al. 2006a,b; Morona and González 2013) including fish (Maler et al. 1984; Denizot et al. 1988; Díaz-Regueira and Anadón 2000; Megías et al. 2003; Castro et al. 2005; Graña et al. 2013), however, many contradictory findings have been described about the presence of these proteins in spinal neuronal populations including motoneurons. In the adult zebrafish, the axial motoneurons form distinct pools related to the type of muscle fibers (slow, intermediate, fast) they innervate (Gabriel et al. 2011; Ampatzis et al. 2013). During swimming, different secondary motoneuron pools are sequentially recruited from slow, to intermediate, and finally to fast to cover the full range of locomotor speeds (Ampatzis et al. 2013). Moreover, the first developed primary motoneurons contribute only to the escape response (Ampatzis et al. 2013) and innervate fast muscle fibers. These findings suggest a differential contribution of axial motoneurons to the generation of locomotion at different speeds and modalities. In this study, we observed that both primary and secondary motoneurons strongly express PV, however, only the primary and some of the secondary fast 
motoneurons were found to contain $\mathrm{CR}$, suggesting the functional significance of the presence of different CBPs in motoneurons to buffer intracellular calcium. In accordance with our results, vertebrate spinal cord motoneurons have been shown to contain CR (xenopus, Morona et al. 2006a, b, rats; lizard; Laslo et al. 2000; primates; Fahandejsaadi et al. 2004) including fish (grey mullet, Díaz-Regueira and Anadón 2000; zebrafish; Castro et al. 2005; lamprey; Megías et al. 2003; lungfish; Morona et al. 2010), however, mammalian spinal motoneurons have been shown to lack PV (Ince et al. 1993; Elliott and Snider 1995). The expression of CB appears to be more variable between different species. In our study, all axial motoneurons in the adult zebrafish spinal cord were found to be $\mathrm{CB}^{-}$. Similar to our observations the motoneurons of the turtle (Morona et al., 2007), and rat (Antal et al. 1990; Ren and Ruda 1994) were observed to lack CB. However, in lizards (Morona et al. 2006a), in primates (Fahandejsaadi et al. 2004), in xenopus (Morona et al. 2006b) and in other fish species several CB containing spinal motoneurons have been observed (Denizot et al. 1988; Díaz-Regueira and Anadón 2000; Megías et al. 2003; Morona et al. 2010). Besides this high variability regarding the presence of CBPs in secondary motoneurons, the prominent expression of $\mathrm{CR}$ in primary motoneurons that we observed has been documented also in other fishes (Denizot et al. 1988; Díaz-Regueira and Anadón 2000; Castro et al. 2005). Finally, we observed that zebrafish motoneurons contain PV, similar to previous studies that suggest the existence of PV in vertebrate brain motor nuclei and in the spinal cord (Philippe et al. 1993; Reiner et al. 1995; Sasaki et al. 2006).

The initiation of all animal body movements depends on the activation of brain descending neurons that project to the spinal cord (Grillner and Jessell 2009; Esposito et al. 2014; Kiehn 2016). The reticulospinal neurons drive the activity of the spinal locomotor networks that are responsible for the generation of locomotion at different speeds and modalities. Moreover, recent findings suggest that the supraspinal descending neurons provide in addition the necessary "stop" signals to terminate any ongoing movement (Bouvier et al. 2015). However, whether there are neuronal subpopulations that constitute functionally distinct modules in descending neurons remain unclear. Here we show that the vast majority of the brain descending neurons to spinal cord express PV and only a fraction of these neurons was found to express $\mathrm{CR}$. Moreover, none of the reticulospinal neurons were observed to contain CB. The presence of CR in a large population of reticulospinal neurons was reported before in fish (Díaz-Regueira and Anadón 2000; Castro et al. 2005; Graña et al. 2012, 2013) as well as in other vertebrate species (Smeets and González 2000; Morona and González 2009). In contrast to previous studies demonstrating the existence of $\mathrm{CB}$ in brain to spinal cord descending neurons (Wang et al. 1996; Goodchild et al. 2000; Morona et al. 2006a,b), we could not reveal the presence of CB in retrogradely labeled zebrafish brain neurons. With regard to the presence of CBPs in the Mauthner cell, a gigantic reticulospinal neuron in the brainstem that generates the escape behavior (Zottoli 1977; Prugh et al. 1982), we found that these cells contain only PV. This observation is in agreement with observations in other teleosts, in which CR was not present in the Mauthner cell body (Crespo et al. 1998; Díaz-Regueira and Anadón 2000; Castro et al. 2005), whereas PV positive Mauthner cell bodies where identified before in tench (Tinca tinca; Crespo et al. 1998). Interestingly, the Mauthner cell axon in the spinal cord was found to lack PV. This is similar to results of previous studies that suggest the complementary expression of CBP in different cellular elements of the Mauthner cell, revealing the existence of a prominent complexity in the calcium buffering system (Crespo et al. 1998).

All three studied CBPs are known to participate in the regulation of intracellular calcium homeostasis, neurotransmitter release and synaptic alterations (Blaustein 1988; Miller 1991; Heizman and Braun 1992; Lledo et al. 1992; Andressen et al. 1993; Chard et al. 1993; Berridge et al. 2000). As such, $\mathrm{Ca}^{2+}$ regulators possess the ability to prevent or attenuate damage to cells due to toxicity that can be caused by the excessive entry of $\mathrm{Ca}^{2+}$ after prolonged neuronal activity (Scharfman and Schwartzkroin 1989). Such protection has been thought to underlie the selective survival, and conversely, selective vulnerability of neurons containing or lacking different CBPs (Morrison et al. 1998). Indeed, the differential expression or deficiency in CBPs in neurons has been suggested to be the key reason for the neuronal vulnerability to the progress of pathophysiological conditions associated with motoneuron degenerative diseases such as amyotrophic lateral sclerosis (ALS) (Ince et al. 1993; Alexianu et al. 1994; Elliott and Snider 1995; Reiner et al. 1995). It has been shown that already at presymptomatic stages of ALS, intracellular calcium levels in spinal motoneurons are increased (Siklos et al. 1998) and CBPs are practically absent (Alexianu et al. 1994; Elliot and Snider 1995; Ince et al. 1993; Reiner et al. 1995) indicating a neuroprotective role for CBPs (Mattson et al. 1991).

If the presence of CBPs could be indeed related to functional neuronal properties, then the anatomical distribution of these proteins holds a potentially exceptional tool for the study of the functional and anatomical organization of the spinal cord networks. More specifically, in mammals $\mathrm{PV}$ is often associated with fast spiking neurons in the hippocampus, in forebrain areas (Celio 1986; Kawaguchi 1993; Kawaguchi and Kubota 1993; Sik et al. 1995) and in the spinal cord (Solbach and Celio 1991). On the other hand, neurons related to sensory processing were shown to contain CR (Ren and Ruda 1994). Recent studies in the cerebellum of mice that lack CR or CB revealed altered firing patterns of granule cells (Gall et al. 2003; Cheron 
et al. 2004): CR-deficient granule cells exhibit faster action potentials and generate repetitive spike discharge. These results suggest that calcium binding proteins modulate neuronal excitability and activity of cerebellar circuits.

In the present study, we observed that cells surrounding the central canal express $\mathrm{CB}$. We further saw that the vast majority of these cells ( $80 \%)$ are neuronal progenitors/ stem cells since they expressed the pluripotency marker Sox-2. From the remaining $\mathrm{CB}^{+}$population, only a small fraction $(\sim 5 \%)$ expressed a neurotransmitter phenotype (Fig. 3b,e). It has been demonstrated that the expression of Sox-2 protein is not uniform (undetectable low-level protein expression) across the entire neural progenitor populations and that can explain the presence of $\mathrm{CB}^{+} / \mathrm{Sox}-$ $2^{-}$cells (Hutton and Pevny 2011; Hagey and Muhr 2014). In the adult zebrafish, as in all vertebrates, the proliferation niche of the spinal cord is situated around the central canal (Grandel et al. 2006; Kaslin et al. 2008; Hui et al. 2015). The main cell population in this area is the ependymal cells in both fish and mammals (Alfaro-Cervello et al. 2012; Hui et al. 2015). It is known that spinal neuronal precursors/stem cells exist within the population of central canal ependymal cells (Meletis et al. 2008). Under physiological conditions, ependymal cells self-renew and produce small numbers of glial progenitors that produce astrocytes and oligodendrocytes (Horner et al. 2000). However, in response to traumatic injury, ependymal cells increase their proliferative activity (Yamada et al. 1997) and act as neural stem cells to generate neuroblasts that proliferate and differentiate into neurons (Anderson et al. 1994; Meletis et al. 2008). In addition, mammalian spinal cord ependymal cells were found to contain CB (Ren and Ruda 1994; Zhang et al. 2016). Therefore, the results of the present study primarily indicate that in adult zebrafish the new born neurons that arise from the central canal ependymal cells use CB to buffer the intracellular calcium. However, once they mature and establish a neurotransmitter typology then the vast majority of these neuron uses $\mathrm{CR}$ and/or PV to mediate the calcium homeostasis.

Acknowledgements This work was supported by a grant from the Swedish Research Council (2015-03359 to K.A.), StratNeuro (to K.A.), Swedish Brain Foundation (FO2016-0007 to K.A.), Erik and Edith Fernström Foundation (FS-2017:0005 to K.A.), Längmanska kulturfonden (BA17-0390 to K.A.) and Deutsche Forschungsgemeinschaft (BE 6245/1-1 to E.M.B.).

\section{Compliance with ethical standards}

Ethical statement All experimental protocols were approved by the local Animal Research Ethical Committee (Jordbruksverket; Ethical permit no. 9248-2017), Stockholm, and were performed in accordance with EU guidelines for the care and use of laboratory animals (86/609/ CEE). All efforts were made to utilize only the minimum number of animals necessary to produce reliable scientific data.
Conflict of interest The authors declare that they have no conflicts of interest.

Open Access This article is distributed under the terms of the Creative Commons Attribution 4.0 International License (http://creativeco mmons.org/licenses/by/4.0/), which permits unrestricted use, distribution, and reproduction in any medium, provided you give appropriate credit to the original author(s) and the source, provide a link to the Creative Commons license, and indicate if changes were made.

\section{References}

Alexianu ME, Ho BK, Mohamed AH, La Bella V, Smith RG, Appel SH (1994) The role of calcium-binding proteins in selective motoneuron vulnerability in amyotrophic lateral sclerosis. Ann Neurol 36:846-858

Alfaro-Cervello C, Soriano-Navarro M, Mirzadeh Z et al (2012) Biciliated ependymal cell proliferation contributes to spinal cord growth. J Comparative Neurol 520:3528-3552. https://doi. org/10.1002/cne.23104

Alvarez FJ, Jonas PC, Sapir T et al (2005) Postnatal phenotype and localization of spinal cord V1 derived interneurons. J Comp Neurol 493:177-192. https://doi.org/10.1002/cne.20711

Ampatzis K, Song J, Ausborn J, El Manira A (2013) Pattern of innervation and recruitment of different classes of motoneurons in adult zebrafish. J Neurosci 33:10875-10886. https://doi.org/10.1523/ JNEUROSCI.0896-13.2013

Ampatzis K, Song J, Ausborn J, El Manira A (2014) Separate microcircuit modules of distinct v2a interneurons and motoneurons control the speed of locomotion. Neuron 83:934-943. https:// doi.org/10.1016/j.neuron.2014.07.018

Anderson MJ, Rossetto DL, Lorenz LA (1994) Neuronal differentiation in vitro from precursor cells of regenerating spinal cord of the adult teleosts Apteronotus albifrons. Cell Tissue Res 278:243-248

Andressen C, Blümcke I, Celio MR (1993) Calcium-binding proteins: selective markers of nerve cells. Cell Tissue Res 271:181-208

Anelli R, Heckman CJ (2005) The calcium binding proteins calbindin, parvalbumin, and calretinin have specific patterns of expression in the gray matter of cat spinal cord. J Neurocytol 34:369-385. https://doi.org/10.1007/s11068-006-8724-2

Antal M, Freund TF, Polgár E (1990) Calcium-binding proteins, parvalbumin- and calbindin-D $28 \mathrm{k}$-immunoreactive neurons in the rat spinal cord and dorsal root ganglia: a light and electron microscopic study. J Comp Neurol 295:467-484. https://doi. org/10.1002/cne.902950310

Antal M, Polgár E, Chalmers J et al (1991) Different populations of parvalbumin- and calbindin-D28k-immunoreactive neurons contain GABA and accumulate $3 \mathrm{H}$-D-aspartate in the dorsal horn of the rat spinal cord. J Comp Neurol 314:114-124. https://doi. org/10.1002/cne.903140111

Aoki E, Semba R, Seto-Ohshima A, Heizmann CW, Kashiwama TAS (1990) Coexistence of parvalbumin and glycine in the rat brainstem. Brain Res 525:140-143

Arai R, Winsky L, Arai M, Jacobowitz DM (1991) Immunohistochemical localization of calretinin in the rat hindbrain. J Comp Neurol 310:21-44. https://doi.org/10.1002/cne.903100105

Arvidsson U, Ulfhake B, Cullheim S, Ramirez V, Shupliakov O, Hökfelt T (1992) Distribution of calbindin-D28k-like activity (Ll) in the monkey ventral horn: do Renshaw cells contain calbindin-D28k-L1? J Neurosci 12:718-728

Ausborn J, Mahmood R, El Manira A (2012) Decoding the rules of recruitment of excitatory interneurons in the adult zebrafish 
locomotor network. Proc Natl Acad Sci USA 109:E3631-E3639. https://doi.org/10.1073/pnas.1216256110

Baimbridge KG, Celio MR, Rogers JH (1992) Calcium-binding proteins in the nervous system. Trends Neurosci 15:303-308

Berkowitz A, Roberts A, Soffe SR (2010) Roles for multifunctional and specialized spinal interneurons during motor pattern generation in tadpoles, zebrafish larvae, and turtles. 4:36. https://doi. org/10.3389/fnbeh.2010.00036

Bernhardt RR, Chitnis AB, Lindamer L, Kuwada JY (1990) Identification of spinal neurons in the embryonic and larval zebrafish. $\mathrm{J}$ Comp Neurol 302:603-616. https://doi.org/10.1002/cne.90302 0315

Berridge MJ, Lipp P, Bootman MD (2000) The versatility and universality of calcium signalling. Nat Rev Mol Cell Biol 1:11-21. https://doi.org/10.1038/35036035

Bikoff JB, Gabitto MI, Rivard AF et al (2016) Spinal Inhibitory interneuron diversity delineates variant motor microcircuits. Cell 1-36. https://doi.org/10.1016/j.cell.2016.01.027

Björnfors ER, El Manira A (2016) Functional diversity of excitatory commissural interneurons in adult zebrafish. eLife 5:e18579. https://doi.org/10.7554/eLife.18579

Blaustein MP (1988) Calcium transport and buffering in neurons. Trends Neurosci 11:438-443

Böhm UL, Prendergast A, Djenoune L et al (2016) CSF-contacting neurons regulate locomotion by relaying mechanical stimuli to spinal circuits. Nat Commun 7:10866. https://doi.org/10.1038/ ncomms 10866

Bouvier J, Caggiano V, Leiras R et al (2015) Descending Command Neurons in the Brainstem that Halt Locomotion. Cell 163:11911203. https://doi.org/10.1016/j.cell.2015.10.074

Bradley S, Tossell K, Lockley R, McDearmid JR (2010) Nitric oxide synthase regulates morphogenesis of zebrafish spinal cord motoneurons. J Neurosci 30:16818-16831. https://doi.org/10.1523/ JNEUROSCI.4456-10.2010

Briscoe J, Ericson J (2001) Specification of neuronal fates in the ventral neural tube. Curr Opin Neurobiol 11:43-49

Carr PA, Alvarez J, Leman EA, Fyffe REW (1998) Calbindin-D28k expression in immunohistochemically identified Renshaw cells. Neuroreport 9:2657-2661

Castro A, Becerra M, Manso MJ, Anadón R (2005) Calretinin immunoreactivity in the brain of the zebrafish, Danio rerio: Distribution and comparison with some neuropeptides and neurotransmittersynthesizing enzymes. II. Midbrain, hindbrain, and rostral spinal cord. J Comp Neurol 494:792-814. https://doi.org/10.1002/ cne. 20843

Celio MR (1986) Parvalbumin in most gamma-aminobutyric acid-containing neurons of the rat cerebral cortex. Science 231:995-997

Celio MR (1990) Calbindin D-28 k and parvalbumin in the rat nervous system. Neuroscience 35:375-475

Chard PS, Bleakman D, Christakos S et al (1993) Calcium buffering properties of calbindin D28k and parvalbumin in rat sensory neurones. J Physiol (Lond) 472:341-357. https://doi.org/10.1113/ jphysiol.1993.sp019950

Cheron G, Gall D, Servais L, Dan B, Maex R, Schiffmann SN (2004) Inactivation of calcium-binding protein genes induces $160 \mathrm{~Hz}$ oscillations in the cerebellar cortex of alert mice. J Neurosci 24:434-441

Clemente D, Porteros Á, Weruaga E et al (2004) Cholinergic elements in the zebrafish central nervous system: Histochemical and immunohistochemical analysis. J Comp Neurol 474:75-107. https://doi.org/10.1002/cne.20111

Crespo C, Arévalo R, Briñón JG et al (1998) Co-localization of calretinin and parvalbumin with nicotinamide adenine dinucleotide phosphate-diaphorase in tench Mauthner cells. Neurosci Lett 250:107-110
Cullheim S, Kellerth J-0 (1981) Two kinds of recurrent inhibition of cat spinal a-motoneurons as differentiated pharmacologically. $\mathrm{J}$ Physiol 312:209-224

Denizot JP, Bratton BO, Bréhier A, Thomasset M (1988) Immunohistochemical demonstration of calbindin-D 28K (CABP28K) in the spinal cord motoneurons of teleost fish. Cell Tissue Res 254:629-634

Díaz-Regueira S, Anadón R (2000) Calretinin expression in specific neuronal systems in the brain of an advanced teleost, the grey mullet (Chelon labrosus). J Comp Neurol 426:81-105

Djenoune L, Desban L, Gomez J et al (2017) The dual developmental origin of spinal cerebrospinal fluid-contacting neurons gives rise to distinct functional subtypes. Sci Rep 7:719. https://doi. org/10.1038/s41598-017-00350-1

Drapeau P, Saint-Amant L, Buss RR et al (2002) Development of the locomotor network in zebrafish. Prog Neurobiol 68:85-111

Elliott JL, Snider WD (1995) Parvalbumin is a marker of ALS-resistant motor neurons. Neuroreport 6:449-452

Episkopou V (2005) SOX2 functions in adult neural stem cells. Trends Neurosci 28:219-221

Esposito MS, Capelli P, Arber S (2014) Brainstem nucleus MdV mediates skilled forelimb motor tasks. Nature. https://doi.org/10.1038/ nature 13023

Fahandejsaadi A, Leung E, Rahaii R, Bu J, Geula C (2004) Calbindin$\mathrm{D} 28 \mathrm{~K}$, parvalbumin and calretinin in primate lower motor neurons. Neuroreport 15:443-448

Ferg M, Armant O, Yang L et al (2014) Gene transcription in the zebrafish embryo: regulators and networks. Briefings Funct Genomics 13:131-143. https://doi.org/10.1093/bfgp/elt044

Ferri AL, Cavallaro M, Braida D, Di Cristofano A, Canta A, Vezzani A, Ottolenghi S, Pandolfi PP, Sala M, DeBiasi S, Nicolis SK (2004) Sox 2 deficiency causes neurodegeneration and impaired neurogenesis in the adult mouse brain. Development 131:3805-3819

Fournet N, Garcia-Segura LM, Norman AW, Orci L (1986) Selective localization of calcium-binding protein in human brainstem, cerebellum and spinal cord. Brain Res 399:310-316

Gabriel JP, Ausborn J, Ampatzis K et al (2011) Principles governing recruitment of motoneurons during swimming in zebrafish. Nat Neurosci 14:93-99. https://doi.org/10.1038/nn.2704

Gall D, Roussel C, Susa I, D’Angelo E, Rossi P, Bearzatto B, Galas MC, Blum D, Schurmans S, Schiffmann SN (2003) Altered neuronal excitability in cerebellar granule cells of mice lacking calretinin. J Neurosci 23:9320 - 9327

Goodchild AK, Llewellyn-Smith IJ, Sun QJ, Chalmers J, Cunningham AM, Pilowsky PM (2000) Calbindin-immunoreactive neurons in the reticular formation of the rat brainstem: catecholamine content and spinal projections. J Comp Neurol 424:547-562

Goulding M (2009) Circuits controlling vertebrate locomotion: moving in a new direction. Nat Rev Neurosci 10:507-518. https://doi. org/10.1038/nrn2608

Goulding M, Lanuza G, Sapir T, Narayan S (2002) The formation of sensorimotor circuits. Curr Opin Neurobiol 12:508-515

Graña P, Huesa G, Anadón R, Yáñez J (2012) Immunohistochemical study of the distribution of calcium binding proteins in the brain of a chondrostean (Acipenser baeri). J Comp Neurol 520:20862122. https://doi.org/10.1002/cne.23030

Graña P, Folgueira M, Huesa G et al (2013) Immunohistochemical distribution of calretinin and calbindin (D-28 k) in the brain of the cladistian Polypterus senegalus. J Comp Neurol 521:2454-2485. https://doi.org/10.1002/cne.23293

Grandel H, Kaslin J, Ganz J et al (2006) Neural stem cells and neurogenesis in the adult zebrafish brain: Origin, proliferation dynamics, migration and cell fate. Dev Biol 295:263-277. https://doi. org/10.1016/j.ydbio.2006.03.040 
Grillner SS (2003) The motor infrastructure: from ion channels to neuronal networks. Nat Rev Neurosci 4:573-586. https://doi. org/10.1038/nrn1137

Grillner S (2006) Biological pattern generation: the cellular and computational logic of networks in motion. Neuron 52:751-766. https://doi.org/10.1016/j.neuron.2006.11.008

Grillner S, Jessell TM (2009) Measured motion: searching for simplicity in spinal locomotor networks. Curr Opin Neurobiol 19:572586. https://doi.org/10.1016/j.conb.2009.10.011

Hagey DW, Muhr J (2014) Sox 2 acts in a dose-dependent fashion to regulate proliferation of cortical progenitors. Cell Rep 9:19081920. https://doi.org/10.1016/j.celrep.2014.11.013

Hale ME, Ritter DA, Fetcho JR (2001) A confocal study of spinal interneurons in living larval zebrafish. J Comp Neurol 437:1-16

Heizmann CW, Braun K (1992) Changes in $\mathrm{Ca}(2+)$-binding proteins in human neurodegenerative disorders. Trends Neurosci 15:259-264

Higashijima S-I, Mandel G, Fetcho JR (2004a) Distribution of prospective glutamatergic, glycinergic, and GABAergic neurons in embryonic and larval zebrafish. J Comp Neurol 480:1-18. https ://doi.org/10.1002/cne.20278

Higashijima S-I, Schaefer M, Fetcho JR (2004b) Neurotransmitter properties of spinal interneurons in embryonic and larval zebrafish. J Comp Neurol 480:19-37. https://doi.org/10.1002/ cne. 20279

Higashijima S-I, Masino MA, Mandel G, Fetcho JR (2004c) Engrailed-1 expression marks a primitive class of inhibitory spinal interneuron. J Neurosci 24:5827-5839. https://doi. org/10.1523/JNEUROSCI.5342-03.2004

Horner PJ, Power AE, Kempermann G, Kuhn HG, Palmer TD et al (2000) Proliferation and differentiation of progenitor cells throughout the intact adult rat spinal cord. J Neurosci 20:2218-2228

Hui SP, Nag TC, Ghosh S (2015) Characterization of proliferating neural progenitors after spinal cord injury in adult zebrafish. PLoS ONE 10:e0143595. https://doi.org/10.1371/journal.pone.01435 95

Hutton SR, Pevny LH (2011) SOX2 expression levels distinguish between neural progenitor populations of the developing dorsal telencephalon. Dev Biol 352:40-47. https://doi.org/10.1016/j. ydbio.2011.01.015

Ince P, Stout N, Shaw P et al (1993) Parvalbumin and calbindin D-28 $\mathrm{k}$ in the human motor system and in motor neuron disease. Neuropathol Appl Neurobiol 19:291-299

Jankowska E (1992) Interneuronal relay in spinal pathways from proprioceptors. Prog Neurobiol 38:335-378

Jessell TM (2000) Neuronal specification in the spinal cord: inductive signals and transcriptional codes. Nat Rev Genet 1:20-29. https ://doi.org/10.1038/35049541

Kaslin J, Ganz J, Brand M (2008) Proliferation, neurogenesis and regeneration in the non-mammalian vertebrate brain. Philos Trans R Soc B: Biol Sci 363:101-122. https://doi.org/10.1098/ rstb.2006.2015

Katsumaru H, Kosaka T, Weizmann CW, Hama K (1988) Immunocytochemical study of GABAergic neurons containing the calcium binding protein parvalbumin in the rat hippocampus. Exp Brain Res 72:347-362

Kawaguchi Y (1993) Physiological, morphological, and histochemical characterization of three classes of interneurons in rat neostriatum. J Neurosci 13:4908-4923

Kawaguchi Y, Kubota Y (1993) Correlation of physiological subgroupings of nonpyramidal cells with parvalbumin- and calbindind $28 \mathrm{k}$-immunoreactive neurons in layer $\mathrm{V}$ of rat frontal cortex. J Neurophysiol 70:387-396
Kiehn O (2006) Locomotor circuits in the mammalian spinal cord. Annu Rev Neurosci 29:279-306. https://doi.org/10.1146/annur ev.neuro.29.051605.112910

Kiehn O (2016) Decoding the organization of spinal circuits that control locomotion. Nature Publishing Group 17:224-238. https:// doi.org/10.1038/nrn.2016.9

Kimura Y, Satou C, Higashijima S-I (2008) V2a and V2b neurons are generated by the final divisions of pair-producing progenitors in the zebrafish spinal cord. Development 135:3001-3005. https:// doi.org/10.1242/dev.024802

Kishore S, Bagnall MW, McLean DL (2014) Systematic shifts in the balance of excitation and inhibition coordinate the activity of axial motor pools at different speeds of locomotion. J Neurosci 34:14046-14054. https://doi.org/10.1523/JNEUR OSCI.0514-14.2014

Kress S, Biechl D, Wullimann MF (2015) Combinatorial analysis of calcium-binding proteins in larval and adult zebrafish primary olfactory system identifies differential olfactory bulb glomerular projection fields. Brain Struct Funct 220:1-20. https://doi. org/10.1007/s00429-014-0765-1

Kuscha V, Barreiro-Iglesias A, Becker CG, Becker T (2012) Plasticity of tyrosine hydroxylase and serotonergic systems in the regenerating spinal cord of adult zebrafish. J Comp Neurol 520:933-951. https://doi.org/10.1002/cne.22739

Laslo P, Lipski J, Nicholson LFB, Miles GB, Funk GD (2000) Calcium binding proteins in motoneurons at low and high risk for degeneration in ALS. NeuroReport 11:3305-3308

Lee SK, Pfaff SL (2001) Transcriptional networks regulating neuronal identity in the developing spinal cord. Nat Neurosci 4 Suppl:1183-1191. https://doi.org/10.1038/nn750

Lewis KE (2006) How do genes regulate simple behaviours? Understanding how different neurons in the vertebrate spinal cord are genetically specified. Philos Trans R Soc B: Biol Sci 361:45-66. https://doi.org/10.1098/rstb.2005.1778

Lledo P-M, Somasundaram B, Morton AJ, Emson PC, Mason WT (1992) Stable transfection of calcium-D28K into the GH3 cell line alters calcium currents and intracellular calcium homeostasis. Neuron 9:943-954

Mahmood R, Restrepo CE, El Manira A (2009) Transmitter phenotypes of commissural interneurons in the lamprey spinal cord. Neuroscience 164:1057-1067. https://doi.org/10.1016/j.neuro science.2009.08.069

Maler L, Jande S, Lawson EM (1984) Localization of vitamin D-dependent calcium binding protein in the electrosensory and electromotor system of high frequency gymnotid fish. Brain Res 301:166-170

Mattson MP, Rychlik B, Chu C, Christakos S (1991) Evidence for calcium-reducing and excitoprotective roles for the calcium- binding protein calbindin-D28K in cultured hippocampal neurons. Neuron 6:41-51

McCrea DA, Rybak IA (2008) Organization of mammalian locomotor rhythm and pattern generation. Brain Res Rev 57:134-146. https ://doi.org/10.1016/j.brainresrev.2007.08.006

McLean DL, Fetcho JR (2004) Ontogeny and innervation patterns of dopaminergic, noradrenergic, and serotonergic neurons in larval zebrafish. J Comp Neurol 480:38-56. https://doi.org/10.1002/ cne. 20280

McLean DL, Fan J, Higashijima S-I, Fetcho JR (2007) A topographic map of recruitment in spinal cord. Nature 446:71-75. https://doi. org/10.1038/nature05588

McPherson AD, Barrios JP, Luks-Morgan SJ et al (2016) Motor behavior mediated by continuously generated dopaminergic neurons in the zebrafish hypothalamus recovers after cell ablation. Curr Biol 26:263-269. https://doi.org/10.1016/j.cub.2015.11.064

Megías M, Alvarez-Otero R, Pombal MA (2003) Calbindin and calretinin immunoreactivities identify different types of neurons in 
the adult lamprey spinal cord. J Comp Neurol 455:72-85. https ://doi.org/10.1002/cne.10473

Meletis K, Barnabé-Heider F, Carlén M et al (2008) Spinal cord injury reveals multilineage differentiation of ependymal cells. Plos Biol 6:e182. https://doi.org/10.1371/journal.pbio.0060182

Menelaou E, VanDunk C, McLean DL (2014) Differences in the morphology of spinal V2a neurons reflect their recruitment order during swimming in larval zebrafish. J Comp Neurol 522:12321248. https://doi.org/10.1002/cne. 23465

Miller RJ (1991) The control of neuronal $\mathrm{Ca}^{2+}$ homeostasis. Prog Neurobiol 37:255-285

Moly PK, Ikenaga T, Kamihagi C et al (2014) Identification of initially appearing glycine-immunoreactive neurons in the embryonic zebrafish brain. Dev Neurobiol 74:616-632. https://doi. org/10.1002/dneu.22158

Montgomery JE, Wiggin TD, Rivera-Perez LM et al (2016) Intraspinal serotonergic neurons consist of two, temporally distinct populations in developing zebrafish. Dev Neurobiol 76:673-687. https ://doi.org/10.1002/dneu.22352

Morona R, González A (2009) Immunohistochemical localization of calbindin-D28k and calretinin in the brainstem of anuran and urodele amphibians. J Comp Neurol 515:503-537. https://doi. org/10.1002/cne.22060

Morona R, González A (2013) Pattern of calbindin-D28k and calretinin immunoreactivity in the brain of Xenopus laevis during embryonic and larval development. J Comp Neurol 521:79-108. https ://doi.org/10.1002/cne.23163

Morona R, López JM, González A (2006a) Calbindin-D28k and calretinin immunoreactivity in the spinal cord of the lizard Gekko gecko: colocalization with choline acetyltransferase and nitric oxide synthase. Brain Res Bull 69:519-534. https://doi. org/10.1016/j.brainresbull.2006.02.022

Morona R, Moreno N, López JM, González A (2006b) Immunohistochemical localization of calbindin-D28k and calretinin in the spinal cord of Xenopus laevis. J Comp Neurol 494:763-783. https://doi.org/10.1002/cne.20836

Morona R, Northcutt RG, González A (2010) Immunohistochemical localization of calbindin-D28k and calretinin in the spinal cord of lungfishes. Brain Behav Evol 76:198-210. https://doi. org/10.1159/000321326

Morrison BM, Hof PR, Morrison JH (1998) Determinants of neuronal vulnerability in neurodegenerative diseases. Ann Neurol 44:S32-S44

Mueller T, Vernier P, Wullimann MF (2004) The adult central nervous cholinergic system of a neurogenetic model animal, the zebrafish Danio rerio. Brain Res 1011:156-169. https://doi.org/10.1016/j. brainres.2004.02.073

Mueller T, Vernier P, Wullimann MF (2006) A phylotypic stage in vertebrate brain development: GABA cell patterns in zebrafish compared with mouse. J Comp Neurol 494:620-634

Ohnmacht J, Yang Y, Maurer GW et al (2016) Spinal motor neurons are regenerated after mechanical lesion and genetic ablation in larval zebrafish. Development 143:1464-1474. https://doi.org/10.1242/ dev.129155

Philippe E, Gaulin F, Audet G, Zhou C (1993) Expression of gammaaminobutyric acid and calcium binding protein- parvalbumin by chick motoneurons. Brain Res Bull 30:325-328

Prugh JI, Kimmel CB, Metcalfe WK (1982) Noninvasive recording of the Mauthner neurone action potential in larval zebrafish. J Experim Biol 101:83-92

Reimer MM, Sörensen I, Kuscha V et al (2008) Motor Neuron Regeneration in Adult Zebrafish. J Neurosci 28:8510-8516. https://doi. org/10.1523/JNEUROSCI.1189-08.2008

Reiner A, Medina L, Figueredo-Cardenas G, Anfinson S (1995) Brain-stem motoneuron pools that are selectively resistant in amyotrophic lateral sclerosis are preferentially enriched in parvalbumin: evidence from monkey brainstem for a calciummediated mechanism in sporadic ALS. Exp Neurol 131:239-250

Ren K, Ruda MA (1994) A comparative study of the calcium-binding proteins calbindin-D28K, calretinin, calmodulin and parvalbumin in the rat spinal cord. Brain Res Rev 19:163-179

Ren K, Ruda MA, Jacobowitz DM (1993) Immunohistochemical localization of calretinin in the dorsal root ganglion and spinal cord of the rat. Brain Res Bull 31:13-22

Résibois A, Rogers JH (1992) Calretinin in rat brain: an immunohistochemical study. Neuroscience 46:101-134

Reynolds GP, Beasley CL (2001) GABAergic neuronal subtypes in the human frontal cortex - development and deficits in schizophrenia. J Chem Neuroanat 22:95-100

Sapir T, Geiman EJ, Wang Z, Velasquez T, Mitsui S, Yoshihara Y, Frank E, Alvarez FJ, Goulding M (2004) Pax6 and engrailed 1 regulate two distinct aspects of Renshaw cell development. J Neurosci 24:1255-1264

Sasaki S, Warita H, Komori T et al (2006) Parvalbumin and calbindin D-28 k immunoreactivity in transgenic mice with a G93A mutant SOD1 gene. Brain Res 1083:196-203. https://doi.org/10.1016/j. brainres.2006.01.129

Satou C, Kimura Y, Kohashi T et al (2009) Functional role of a specialized class of spinal commissural inhibitory neurons during fast escapes in zebrafish. J Neurosci 29:6780-6793. https://doi. org/10.1523/JNEUROSCI.0801-09.2009

Satou C, Kimura Y, Higashijima S-I (2012) Generation of multiple classes of V0 neurons in zebrafish spinal cord: progenitor heterogeneity and temporal control of neuronal diversity. J Neurosci 32:1771-1783. https://doi.org/10.1523/JNEUR OSCI.5500-11.2012

Scharfman HE, Schwartzkroin PA (1989) Protection of dentate hilar cells from prolonged stimulation by intracellular calcium chelation. Science 246:257-260

Schneider SP, Fyffe RE (1992) Involvement of GABA and glycine in recurrent inhibition of spinal motoneurons. J Neurophysiol 68:397-406

Schwaller B, Meyer M, Schiffmann S (2002) 'New' functions for "old" proteins: the role of the calcium-binding proteins calbindin D-28 $\mathrm{k}$, calretinin and parvalbumin, in cerebellar physiology. Studies with knockout mice. Cerebellum 1:241-258. https://doi. org/10.1080/147342202320883551

Sik A, Penttonen M, Ylinen A, Buzsaki G (1995) Hippocampal CA1 interneurons: an in vivo intracellular labeling study. J Neurosci 15:6651-6665

Siklos L, Engelhardt JI, Alexianu ME, Gurney ME, Siddique T, Appel SH (1998) Intracellular calcium parallels motoneuron degeneration in SOD-1 mutant mice. J Neuropathol Exp Neurol 57:571-587

Smeets WJ, González A (2000) Catecholamine systems in the brain of vertebrates: new perspectives through a comparative approach. Brain Res Brain Res Rev 33:308-379

Solbach S, Celio MR (1991) Ontogeny of the calcium binding protein parvalbumin in the rat nervous system. Anat Embryol 184:103-124

Sueiro C, Carrera I, Molist P et al (2004) Distribution and development of glutamic acid decarboxylase immunoreactivity in the spinal cord of the dogfish Scyliorhinus canicula (elasmobranchs). J Comp Neurol 478:189-206. https://doi.org/10.1002/cne.20285

Takahashi K, Yamanaka S (2006) Induction of pluripotent stem cells from mouse embryonic and adult fibroblast cultures by defined factors. Cell 126:663-676

Wang YJ, Liu CL, Tseng GF (1996) Compartmentalization of calbindin and parvalbumin in different parts of rat rubrospinal neurons. Neuroscience 74:427-434

Wegner M, Stolt CC (2005) From stem cells to neurons and glia: a Soxist's view of neural development. Trends Neurosci 28:583-588 
Windhorst U (2007) Muscle proprioceptive feedback and spinal networks. Brain Res Bull 73:155-202. https://doi.org/10.1016/j. brainresbull.2007.03.010

Wullimann MF, Rupp B, Reichert H (1996) Neuroanatomy of the zebrafish brain: a topological atlas. Birkhaeuser Verlag, Basel

Yamada H, Miyake T, Kitamura T (1997) Proliferation and differentiation of ependymal cells after transection of the carp spinal cord. Zool Sci 14:331-338
Zhang M-D, Barde S, Szodorai E et al (2016) Comparative anatomical distribution of neuronal calcium-binding protein (NECAB) 1 and -2 in rodent and human spinal cord. Brain Struct Funct 221:3803-3823. https://doi.org/10.1007/s00429-016-1191-3

Zottoli SJ (1977) Correlation of the startle reflex and Mauthner cell auditory responses in unrestrained goldfish. J Exp Biol $66: 243-254$ 